2014-03-01

\title{
Traces of ancient mafic layers in the Tethys oceanic mantle
}

Sergeev, DS

http://hdl.handle.net/10026.1/10622

10.1016/j.epsl.2013.10.039

Earth and Planetary Science Letters

All content in PEARL is protected by copyright law. Author manuscripts are made available in accordance with publisher policies. Please cite only the published version using the details provided on the item record or document. In the absence of an open licence (e.g. Creative Commons), permissions for further reuse of content should be sought from the publisher or author. 


\title{
Traces of ancient mafic layers in the Tethys oceanic mantle
}

\author{
Dmitry S. Sergeev ${ }^{1}$, Arjan H. Dijkstra ${ }^{1,2}$,Thomas Meisel ${ }^{3}$,Gerhard Brügmann $^{4}$ \& Sergey A. \\ Sergeev ${ }^{5}$
}

${ }^{1}$ Centre for Hydrogeology and Geothermics, University of Neuchâtel, Neuchâtel 2009, Switzerland

${ }^{2}$ Centre for Research in Earth Sciences, University of Plymouth, PL4 8AA, United Kingdom

${ }^{3}$ Department of General and Analytical Chemistry, Montanuniversität, Leoben 8700, Austria

${ }^{4}$ Institut für Geowissenschaften, Johannes Gutenberg-Universität, Mainz 55099, Germany

${ }^{5}$ Centre of Isotopic Research, VSEGEI, 199106, Sredny Pr. 74, St.-Petersburg, Russia

\section{ABSTRACT}

Oceanic basalts are formed by melting of a chemically and isotopically heterogeneous mantle source. The oceanic mantle probably resembles a marble cake containing layers of mafic rock - perhaps recycled ocean crust - stored in the mantle for $>1$ billion years. Many questions about the nature and distribution of these mantle heterogeneities remain. Here we show that lithological and isotopic traces of ancient mafic layers can still be seen in mantle rocks that have melted to form oceanic crust at a spreading centre in the Tethys Ocean. We have found centimetre-scale heterogeneity in initial osmium isotope ratios in mantle rocks from the Pindos Ophiolite. Deformed pyroxenite layers have high ${ }^{187} \mathrm{Os} /{ }^{188} \mathrm{Os}$ ratios $(0.14-0.20)$ compared to adjacent host peridotites $\left({ }^{187} \mathrm{Os} /{ }^{188}\right.$ Os: $\left.0.12-0.13\right)$. These layers were formed by a reaction between mantle rock and melt derived from ancient rocks with high Re/Os ratios. We interpret the pyroxenite layers as the wall rocks of billion-year old mafic layers that melted and transformed mantle peridotite into pyroxenite by melt-rock reaction. The pyroxenite layers are the melting residue of ancient metre-scale basaltic veins in a kilometre-sized marble cake domain in the oceanic mantle that has withstood homogenization on a billionyear time scale.

\section{Introduction}

The chemical and isotopic compositions of ocean island basalts (OIB) and mid-ocean ridge basalts (MORB) show that their source, the convecting oceanic mantle, is remarkably heterogeneous (e.g., Hofmann, 1997). The oceanic mantle probably contains unhomogenized domains of extensively melted mantle that record an ancient, Proterozoic and Archean melting history (Meibom et al., 2002; Harvey et al., 2006, Pearson et al., 2007; Liu et al., 2008, Dijkstra et al., 2010). Moreover, it is widely assumed that the oceanic mantle contains layers of basaltic composition, possibly subducted oceanic crust, in the form of eclogitic or granulitic pyroxenites (Hofmann \& White, 1982; Allègre \& Turcotte, 1986; Morishita et al., 2004, Kogiso et al., 2004; Donelly et al., 2004; Meibom et al., 2004; Sobolev et al., 2007). This notion has led to the coining of the phrase 'marble cake mantle' (Allègre \& Turcotte, 1986). Melting of a mixed peridotite-pyroxenite source underneath ocean islands and mid-ocean ridges can explain the composition of OIB and MORB (Hirschmann \& Stolper, 1996; Niu \& Batiza, 1997; Kogiso et al., 2004; Donelly et al., 2004, Sobolev et al., 2007; Lassiter et al., 2000). Pyroxenite layers are also the most common lithological heterogeneities in mantle xenoliths and in peridotite massifs derived from the subcontinental lithospheric mantle (Jacob et al., 2005; Garrido \& Bodinier, 1999; Downes, 2007; Van Acken et al., 2010). These continental mantle pyroxenites are generally interpreted as high-pressure magmatic veins (Garrido \& Bodinier, 1999; Downes, 2007), but some may represent ancient recycled ocean crust (Blichert-Toft et al., 1999; Morishita et al., 2004; Jacob et al., 2005), or veins made from melts derived from recycled oceanic material (Pearson et al., 1993; Garrido \& Bodinier, 1999; Downes, 2007; Bodinier et al. 2008; Van Acken et al., 2010; Montanini et al., 2012).

Critically, the presence of isotopic heterogeneities associated with geologically old basaltic (mafic) lithologies in the oceanic mantle has not been confirmed directly in oceanic mantle rocks, even though it is a requirement of basalt petrogenesis models (e.g., Hirschmann \& Stolper, 1996; Sobolev et al., 2007). In contrast to continental mantle, oceanic mantle is continuously stirred by convection, and the discovery of distinct ancient unhomogenized pyroxenite layers would place important limits on the effectiveness of this stirring in homogenizing the mantle. Samples of fossil oceanic mantle are widely available and easily accessible in ophiolites. Mantle pyroxenites are common in ophiolites, but so far it has never been shown that any of these are residues of ancient mantle heterogeneities that were present during partial melting at depth, i.e., mantle heterogeneities that contributed to basalt production. It is commonly assumed that ophiolitic mantle pyroxenites are late-stage igneous products of mantle melts that crystallized in the oceanic lithosphere at a spreading centre or off-axis (e.g., Dantas et al., 2007). It is also widely believed that mafic mantle heterogeneities, if present, melt out completely during mantle upwelling underneath spreading centres (Allègre \& Turcotte, 1986).

We have tested whether lithological and isotopic relics of the marble cake mantle may have been preserved in 
refractory mantle rocks from a ridge system. In our study we used the Re-Os radiogenic isotope system, because, due to the compatible behaviour of the daughter element Os and the long half-life of $42 \mathrm{Ga}$ (Smoliar et al., 1996), the ${ }^{187} \mathrm{Re}-{ }^{188}$ Os decay system is well-suited to study mantle rocks and has the potential to 'look through' recent melting and other ridge processes into the older mantle source history.

\section{Geological setting}

\subsection{The Dramala Complex, Greece}

We have carried out a field and geochemical study focusing on the Dramala Complex (figure 1), the uppermost of the main thrust sheets that make up the Mesozoic Pindos Ophiolite in Northern Greece. The Dramala Complex is dominated by mantle rocks, but an undisturbed intrusive contact with plutonic, mostly cumulate rocks with MORB-characteristics is locally preserved (Rassios \& Moores, 2006). The Dramala Complex tectonically overlies another major thrust sheet, the Aspropotamos Complex, and the contact is marked by slivers of metamorphic sole rocks (see also figure SI-1 in supplementary information). The Aspropotamos Complex chiefly consists of plutonic and volcanic rocks with MORB, island arc tholeiite and boninitic affinities, and has therefore clear supra-subduction zone characteristics (Jones et al., 1991; Saccani and Photiades, 2004; Pe-Piper et al., 2004). Both the Dramala Complex and the Aspropotamos Complex overlie an ophiolitic melange unit, the Avdella Melange (Jones et al., 1991). The melange unit also contains some smaller bodies of (serpentinised) mantle rocks, possibly with supra-subduction zone affinities, but these have not been included in our study.

The Dramala mantle rocks are, however, representative for typical abyssal peridotites (i.e., residues of MORB-source mantle) with regards to their moderately refractory character. Spinel Cr-numbers, i.e., molar ratios of $100 \mathrm{Cr} /(\mathrm{Cr}+\mathrm{Al})$, in harzburgites are 30-55 (Pelletier at al., 2008), corresponding to moderate to moderately-high degrees (14-18\%) of near-fractional melting and melt extraction according to the relation of Hellebrand et al. (2001). Generally, spinel Cr-numbers $>60$ are considered indicative of mantle that melted to high-degrees in suprasubduction zone environments in the presence of a hydrous melt or aqueous fluid (e.g., Pearce, 2003). Importantly, Pelletier and co-workers (2008) showed that B (as well as $\mathrm{Li}$ and $\mathrm{Be}$ ) concentrations in Dramala mantle rocks and in primary mantle minerals are identical to those in abyssal peridotites, ruling out any significant imprint of supra-subduction zone hydrous fluid input or of fluid flux-melting. Moreover, the Dramala Complex has no economically significant chromitite deposits, unlike typical ophiolites formed or strongly modified in supra-subduction zone spreading environments (Rassios \& Moores, 2006; Brenker et al., 2003; Büchl et al., 2004).
Constraints on the age of melting and igneous activity at the Mesozoic spreading centre recorded in the Dramala peridotites, are indirect. Zircons from a plagiogranite from a block of plutonic rocks in the Avdella Melange Unit were dated at $171.3 \pm 3.1 \mathrm{Ma}$ by means of U-Pb SHRIMP dating (Liati et al., 2004). As this sample is not from the Dramala Complex, it is unclear how this age relates to the age of melting of the Dramala peridotites. Metamorphic rocks that line the sole thrusts of the different thrust sheets in the Pindos Ophiolite, including that of the Dramala Complex, have been dated using Ar-Ar methods at $167 \pm 4 \mathrm{Ma}$ (see Smith, 1993). As these ages are interpreted as the start of the ophiolite emplacement process, they give a minimum age for the age of melting in the Dramala mantle. Throughout the paper, an age of $170 \mathrm{Ma}$ is assumed for the age corrections of the reported isotope measurements. Assuming a slightly older (i.e., late-Triassic, see figure SI-1 in supplementary information) age for the age of mantle melting would not change the conclusions in this paper.

\subsection{Mantle layering in the Dramala Complex}

Our studies have focused on a km-sized structural domain with predominantly coarse-grained mantle tectonites, immediately SE of a km-scale mantle shear zone and 1-2 km below the crust-mantle boundary in the NE part of the Dramala Massif (figure 1b). This domain is characterised by peridotites with olivine recrystallized grain sizes of 2-10 mm and well-organized olivine substructures, i.e., with straight, widely-spaced subgrain boundaries and without undulose extinction. These microstructures are indicative of low stress $(<10 \mathrm{MPa})$ mantle flow at temperatures around or above the peridotite solidus (e.g., Ceuleneer \& Rabinowicz, 1992) without any significant overprint of lower temperature deformation. At several localities in this domain, a distinctive 'mantle layering' has been preserved, consisting of $2-15 \mathrm{~cm}$ thick alternating layers of dunite, pyroxene-poor and pyroxene-rich harzburgite, and concordant pyroxenite, all transposed parallel to the mantle deformation fabric (figure 2a-c). The high-temperature mantle flow fabrics are the earliest deformation structures that we observed in the Dramala Complex, which makes the mantle layering the structurally oldest observed feature in the mantle. The mantle layering is cut by a suite of $2 \mathrm{~cm}$ to $10 \mathrm{~m}$ wide discordant, late-stage pyroxenites with cumulate textures (figure 2c). The mantle layering is also cut and deformed by a kmwide shear zone made of mylonitic mantle rocks (figure 1b) that is probably associated with the earliest emplacement of the Dramala Complex. The late-stage cumulate pyroxenites are seen to cross-cut mylonitic mantle rocks, and are thus structurally distinct from the older pyroxenites which are part of the mantle layering.

Pyroxenites from the early mantle layering are websterites consisting predominantly of orthopyroxene, with additionally $10-20 \%$ modal clinopyroxene, $10-35 \%$ olivine, $1-3 \%$ spinel, and $0-3 \%(\mathrm{Fe}, \mathrm{Ni}, \mathrm{Cu})$-sulfide. These concordant websterites are very refractory, with 0.7-3.6 
mass $\% \mathrm{Al}_{2} \mathrm{O}_{3}$ and 0.5-0.9 mass $\% \mathrm{Cr}_{2} \mathrm{O}_{3}$ (see supplementary data table SI-1). At the thin section scale, olivine is concentrated in mm-scale peridotite enclaves with irregular outlines within the pyroxenites, in cases rimmed by clinopyroxene-rich margins. Orthopyroxene grains within the pyroxenites contain abundant inclusions of clinopyroxene, olivine, and olivine+clinopyroxene. These inclusions form orientation families, and inclusions belonging to the same orientation family can be seen in adjacent orthopyroxene crystals (figure $2 \mathrm{~d}$ ). These textures indicate crystallization of clinopyroxene followed by formation of orthopyroxene at the expense of olivine and clinopyroxene. These textures are unlike typical igneous crystallization textures in cumulate pyroxenites. Instead, the textures clearly suggest that the concordant pyroxenites are replacive products of melt-rock reactions between peridotite and pyroxene-saturated melts. Such replacive origins have also been proposed for several types of pyroxenites in continental and in sub-arc mantle massifs (Burg et al., 1998; Garrido \& Bodinier, 1999; Berly et al, 2006; Garrido et al., 2007; Bodinier et al., 2008; Van Acken et al., 2010; Lambart et al., 2012; Marchesi et al., 2013).

\section{Analytical methods}

Highly altered zones were removed from the samples with a diamond disc saw. Pyroxenites were cut from the enclosing peridotites with a diamond disc saw and cut into $5-10 \mathrm{~cm}$ pieces; the outer $3-5 \mathrm{~mm}$ contact zones of the pyroxenites with the enclosing peridotites were not included in the pyroxenite sample. Cut blocks were then cleaned in an ultrasonic bath in distilled water for at least 30 minutes to remove contaminations from the saw blade.

To make powders we used a two-step approach. The first step was to crush the sample to $<3 \mathrm{~mm}$ sized fragments by means of a high-voltage pulsed process for selective fragmentation ("SelFrag", Kerzers, Switzerland) at the University of Bern, Switzerland. A typical 1-3 kg sample immersed in water is fractured by frequent (c. 100-300 pulses) $125-135 \mathrm{kV}$ electrical pulses. The size of the resulting fragments is controlled by a metal grid in the base of the upper sample vessel, through which the fragments fall into a plastic sample bag in the lower sample container. This method drastically reduces the amount of metal contamination compared to conventional crushing techniques using a jaw-crusher. However, very small metal particles $(<100 \mu \mathrm{m})$, often in the form of spherules, coming from the cathode, were found in the crushate. These were removed by sieving and discarding the -100 $\mu \mathrm{m}$ fraction. The second step was to mill the crushed sample to a fine powder using an agate puck-and-ring mill. Whole rock major and minor element concentrations were determined by XRF analysis at the University of Fribourg, Switzerland.

${ }^{187} \mathrm{Os} /{ }^{188} \mathrm{Os}$ isotope ratio and $\mathrm{Ru}, \mathrm{Rh}, \mathrm{Pd}, \mathrm{Re}, \mathrm{Ir}, \mathrm{Pt}$ concentrations in peridotites and pyroxenites were determined using the method of isotope dilution described by Meisel et al. (2003) on a quadrupole ICP mass- spectrometer (HP 7500, Agilent Technologies) at the Montanuniversität Leoben, Austria. All solutions were prepared with ultra-pure water (Milli-Q, Millipore Coorperation). For analyses we used sub-boiled GR $30 \%$ $(\mathrm{m} / \mathrm{m})$ hydrochloric and $65 \%(\mathrm{~m} / \mathrm{m})$ nitric acids (Merck, Darmstadt). Two grams $( \pm 10 \%)$ of fine powdered samples were transferred into $50 \mathrm{ml}$ quartz glass beakers, with the addition of a ${ }^{99} \mathrm{Ru},{ }^{108} \mathrm{Pd},{ }^{185} \mathrm{Re},{ }^{190} \mathrm{Os},{ }^{191} \mathrm{Ir},{ }^{198} \mathrm{Pt}$ mixed spike, and dissolved in a mixture of $5 \mathrm{ml} \mathrm{HNO}_{3}$ and $2 \mathrm{ml} \mathrm{HCl}$. Vials were closed leak-proof with Teflon tape and a quartz glass lid. In one digestion run, five samples, plus one reference material (i.e., Certified PGE Reference Material Diabase Rock Material TDB-1 (CANMET), Reference Materials komatiite OKUM (IAG) and dunite GAS (CGL), and one blank, were dissolved in a High Pressure Asher (HPA) system (Anton Paar - Perkin-Elmer Instruments, Graz) at $300^{\circ} \mathrm{C}$ and at a pressure of 125 bar for four hours. Vials were weighed before and after entering HPA, to assess mass loss. After cooling of the solutions, the Os isotope ratio and concentration were measured as volatile $\mathrm{OsO}_{4}$, which was sparged directly into the ICP-MS following the method of Hassler et al. (2000). The bias and precision of the Os isotope ratio measurements were monitored with $1 \mathrm{ng}$ in total of LOsST Os solution also sparged into the intrument. Repeated measurement of this interlaboratory comparison material gave in average 0.1069 with an intermediate precision standard deviation of less than $1 \%$, which was considered fit-for-the purpose. The residue was centrifuged and dried down on a hot plate. Subsequently, 1.5 $\mathrm{ml} 0.1 \mathrm{~mol} \mathrm{l}^{-1} \mathrm{HCl}$ was added and the solution was heated. The solution was filtered and 1-1.5 $\mathrm{ml}$ of the solution was introduced into a cation-exchange resin column (Dowex AG50Wx8 200-400 mesh, Fluka, Switzerland). The column with a ca. $13 \mathrm{ml}$ volume (1m long, $4.2 \mathrm{~mm}$ diameter tube) was under pressurized ( 2 bar) to ensure the passing of sample trough the resin. The exit was connected directly to the tubing system of the peristaltic pump of the mass spectrometer. For analyses a quartz nebulizer and Ni cones were used.

At the beginning and at the end of each analysis an internal standard solution containing all PGE and Re was measured, then a column blank to monitor the background values (usually about 50 counts $\mathrm{s}^{-1}$ ). Subsequently, the sample was introduced into the column. The elution of PGE's and Re typically took about 30 minutes. Peaks for other elements ( $\mathrm{ZrO}, \mathrm{Cd}, \mathrm{Hg}$ and others) that could cause interferences on PGE and Re in the ICP-MS appeared much later. By monitoring it is possible to take just the interference-free part of the signal for the subsequent concentration calculations. Concentrations were calculated on different isotope ratios: for $\mathrm{Ru}:{ }^{101} \mathrm{Ru} /{ }^{99} \mathrm{Ru}$ and ${ }^{102} \mathrm{Ru} /{ }^{99} \mathrm{Ru}$; for $\mathrm{Pd}$ : ${ }^{105} \mathrm{Pd} /{ }^{108} \mathrm{Pd},{ }^{106} \mathrm{Pd} /{ }^{108} \mathrm{Pd}$ and ${ }^{105} \mathrm{Pd} /{ }^{106} \mathrm{Pd}$; for Re: ${ }^{187} \mathrm{Re} /{ }^{185} \mathrm{Re}$; for Os: ${ }^{192} \mathrm{Os} /{ }^{190} \mathrm{Os}$; for Ir: ${ }^{193} \mathrm{Ir} /{ }^{191} \mathrm{Ir}$ and for $\mathrm{Pt}:{ }^{194} \mathrm{Pt} /{ }^{198} \mathrm{Pt},{ }^{195} \mathrm{Pt} /{ }^{198} \mathrm{Pt}$. This procedure has the advantage compared to other methods that on-line monitoring is possible, and that sample preparation work is relatively simple, allowing for instance to keep the blanks as low as the acid blanks used by HPA digestion. 
Measurement uncertainties of the average of 7 independent concentration measurement of TDB-1 were found to be less $15 \%$ relative. Concentrations of Os, Ir and $\mathrm{Ru}$ are not certified but compare very well with published ID-MS data. Too few data exists for OKUM to compare to our data set. As the HSE concentrations in our samples are generally in the $1-20 \mathrm{ng} / \mathrm{g}$ range, the combined uncertainty for measurement for all HSE in this range is estimated to be less than $15 \%$ relatively.

To test for any bias of the method described above with respect to other methods, we also analyzed a small sample sub-set using a modified 'conventional' measurement procedure, described by Birck et al. (1997) and Rehkamper et al. (1997). Repeated sample measurements on Br-extracted Os isotopes were measured on a Triton (Thermo) Negative-ion Thermal Ionization Mass spectrometer (N-TIMS), and PGE and Re concentrations were measured on single-collector Element-2 (Thermo) ICP-MS, both in the Centre of Isotope Research in St.-Petersburg, Russia. For analyses, Merck analytical grade and suprapure acids were used, which were further purified 2-3 times by sub-boiling and bottleto-bottle procedures. Two gram sample powders and 300 mg ${ }^{185} \mathrm{Re}-{ }^{190} \mathrm{Os}$ and $300 \mathrm{mg}{ }^{191} \mathrm{Ir}^{101}{ }^{10 u}{ }^{198}{ }^{19 t}{ }^{106} \mathrm{Pd}$ tracer were added together. After addition of $3 \mathrm{ml} 11 \mathrm{~mol} / \mathrm{l} \mathrm{HCl}$, samples were frozen by $-20^{\circ} \mathrm{C}$. Subsequently, $7 \mathrm{ml} 14$ $\mathrm{mol} / 1 \mathrm{HNO}_{3}$ was added. As in the previous case the samples were dissolved in $90 \mathrm{ml}$ quartz glass vials in a highpressure asher at $300^{\circ} \mathrm{C}, 125$ bars for 16 hours. Os was educed by a bromine extraction and microdistillation. After digestion samples were poured into $60 \mathrm{ml}$ Savillex Teflon beakers with the addition of $1 \mathrm{ml}$ bromine and left for one hour on a shaker. Br was drawn off by a pipette and evaporated with the addition of $1 \mathrm{ml}$ conc. HBr. Subsequently, the sample was transferred in one drop of acetone onto a lid inside of a conic Savillex Teflon beaker and evaporated again. Subsequently, one drop of 40 $\%(\mathrm{~m} / \mathrm{m})$ sodium dichromate in $12 \mathrm{~mol} / 1 \mathrm{H}_{2} \mathrm{SO}_{4}$ was added, while $5 \mu 1$ conc. $\mathrm{HBr}$ was stored on the conic part of the beaker. The vial was left cone-up for four hours on a hot plate to concentrate $\mathrm{Os}$ in the $\mathrm{HBr}$ microdrop. For measurements, Os in form of bromides was transferred onto $\mathrm{Pt}$ tapes together with $0.2 \mu \mathrm{Ba}(\mathrm{OH})_{2}+\mathrm{NaOH}$ emitter. An installation for oxygen inlet $\left(\mathrm{P}=2 \cdot 10^{-7}\right.$ bar $)$ to the mass spectrometer chamber and cooling by liquid nitrogen were used under a vacuum of $7 \cdot 10^{-8}$ bar. Temperature of tape heating was at $730-750{ }^{\circ} \mathrm{C}$.

The solution with the remaining platinum group elements and Re passed through a $2 \mathrm{ml}$ ion-exchange column (1x8 AG BioRad, 100-200 mesh). The fractions were collected in series: Ru in $10 \mathrm{ml} 11 \mathrm{~mol} / 1 \mathrm{HCl}$; Re in $14 \mathrm{ml} 4 \mathrm{~mol} / 1 \mathrm{HNO}_{3}$; Pd $10 \mathrm{ml} 10 \mathrm{~mol} / 1 \mathrm{HNO}_{3}$; Ir and Pt

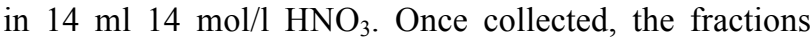
were evaporated and transferred into $2 \mathrm{ml}$ of $3 \%(\mathrm{~m} / \mathrm{m})$ $\mathrm{HNO}_{3}$.

For analyses a quartz nebulizer and $\mathrm{Ni}$ cones were used. Measurements were run on the middle resolution in dynamic regime. For mass-bias correction the following elements with $1 \mu \mathrm{g} / \mathrm{g}$ concentration each were added: Mo for $\mathrm{Ru}, \mathrm{Ag}$ for $\mathrm{Pd}$, Ir and $\mathrm{Re}$. Isotope rations used for cor- rection: ${ }^{95} \mathrm{Mo} /{ }^{97} \mathrm{Mo}=1.6670,{ }^{107} \mathrm{Ag} /{ }^{109} \mathrm{Ag}=1.0764$, ${ }^{191} \mathrm{Ir} /{ }^{193} \mathrm{Ir}=0.5949,{ }^{195} \mathrm{Pt} /{ }^{194} \mathrm{Pt}=1.026238 .{ }^{198} \mathrm{Pt}$ was corrected for ${ }^{198} \mathrm{Hg}$ on ${ }^{199} \mathrm{Hg}$. Analytical blanks were at: $\mathrm{Re}-$ $0.15 \mathrm{ng}$, Os $-0.02 \mathrm{ng}, \mathrm{Ru}-0.07 \mathrm{ng}, \mathrm{Pd}-0.27 \mathrm{ng}, \mathrm{Ir}-$ $0.05 \mathrm{ng}, \mathrm{Pt}-0.06 \mathrm{ng}$. Precision of element concentration measurements on duplicated samples were 1-6\%, and 0.5$1 \%$ for the ${ }^{187} \mathrm{Os} /{ }^{188} \mathrm{Os}$ isotope ratio measurements.

\section{Results - Os isotopic mantle heterogeneity}

Highly Siderophile Elements (HSE, i.e., Os, Ir, Ru, Pt, $\mathrm{Pd}, \mathrm{Re})$ and ${ }^{187} \mathrm{Os} /{ }^{188} \mathrm{Os}$ isotope ratios were measured in whole rock samples of concordant pyroxenite. For comparison, we also analyzed peridotite, as well as samples from late-stage, cross-cutting cumulate pyroxenite dykes. Results (table 1) show that concentrations of the compatible, Ir-like Platinum Group Elements (IPGE, i.e., Os, Ir, $\mathrm{Ru}$ ) in concordant pyroxenites are high, similar to or up to three times higher than in peridotite (figure $3 a, b$ ). Some concordant pyroxenites also have peridotite-like $\mathrm{Pt}$, $\mathrm{Pd}$ and $\mathrm{Re}$ concentrations, but most concordant pyroxenites show a variable enrichment in these more incompatible HSE, correlated with the observed abundance of secondary sulfides. Elevated $\mathrm{Pt}$ and $\mathrm{Pd}$ concentrations in concordant pyroxenite layers are not generally correlated with elevated IPGE concentrations, and there is evidence that $\mathrm{Pt}$ and $\mathrm{Pd}$ are 'decoupled' from the IPGE, and are probably hosted by different phases (see figure SI-2 and figure caption for some discussion). The two crosscutting pyroxenite dykes have markedly different HSE concentration patterns from the peridotites and concordant pyroxenites, with very low concentrations of IPGE, high Pt, but low Re.

Peridotite samples without obvious mantle layering and peridotites from composite peridotite-pyroxenite samples have chondritic to subchondritic (Meisel et al., 1996) ${ }^{187} \mathrm{Os} /{ }^{188} \mathrm{Os}$ ratios $(0.1207-0.1291)$ that are similar to slightly lower than values found in other Mesozoic ophiolites (figure 3c-d; Walker et al., 2002). The two cross-cutting pyroxenites have peridotite-like ${ }^{187} \mathrm{Os} /{ }^{188} \mathrm{Os}$ ratios (0.1256-0.1308), suggesting that they formed by crystallization from peridotite-derived melt. This type of pyroxenite is therefore interpreted as cumulate formed at the ridge system. Because of low Re/Os ratios, corrections to the age of the ophiolite (170 Ma) are minor.

In contrast, the concordant pyroxenites are all suprachondritic $\left({ }^{187} \mathrm{Os} /{ }^{188} \mathrm{Os}=0.1418-0.1980\right)$, markedly more radiogenic than the samples of enclosing peridotite (figure 3 ), in many cases taken only centimetres away. The lowest value is found in a very thin $(0.5 \mathrm{~cm})$ pyroxenite. Some of the sulfide-bearing concordant pyoxenites have elevated $\mathrm{Re} / \mathrm{Os}$ ratios, but the Os isotope ratios of the peridotites and the pyroxenite layers calculated back to $170 \mathrm{Ma}$, expressed in table 1 as $\gamma \mathrm{Os}(170)$ (i.e., percent deviation from a chondritic mantle reservoir), show that peridotites and concordant pyroxenites had different initial Os isotope ratios at that time. $\gamma \mathrm{Os}(170)$ is typically negative for peridotites, whereas values for pyroxenites are in the range +9.4 to +47.9 . Clearly, the radiogenic 
character of the pyroxenites was not produced by radiogenic ingrowth within the pyroxenites themselves, but requires the presence of a radiogenic 'exotic' component.

\section{Discussion}

\subsection{Hybrid pyroxenites formed by melt-rock reaction}

Any petrological model for the formation of the concordant pyroxenite layers must account for: (1) their replacive textures, which indicate that they formed by meltrock reaction; (2) their high, peridotite-like Os, Ir and $\mathrm{Ru}$ concentrations, requiring that they formed from peridotite; (3) their radiogenic Os isotopic signature; (4) the cmscale Os isotope heterogeneity in the mantle layering domain, i.e., from pyroxenite layers into immediately adjacent peridotite. The only petrogenetic models that can explain all the above features involve a reaction between peridotite and an exotic silica-rich agent with a radiogenic ${ }^{187} \mathrm{Os} /{ }^{188} \mathrm{Os}$ isotope ratio. Similar reactions between peridotites and silica-rich melts or fluids have been suggested to play a key role in the formation of pyroxenites within subcontinental mantle (Kelemen et al., 1998; Garrido \& Bodinier, 1999; Bodinier et al., 2008; Van Acken et al., 2010) and in supra-subduction zone oceanic mantle (Batanova \& Sobolev, 2000; Berly et al., 2006; Garrido et al., 2007; Dhuime et al., 2007; Ackerman et al., 2009).

\subsection{A slab-derived metasomatic agent?}

In the case of supra-subduction zone mantle, it has been proposed that silica-rich aqueous fluid or hydrous melt, in part derived from slab-melting or dehydration, can react with shallow-level mantle wedge peridotite and precipitate pyroxene at the expense of olivine (Kelemen et al., 1998) thus producing reaction-type 'hybrid pyroxenite' (Berly et al., 2006; Ackerman et al., 2009). We explored the viability of this model for the Dramala case, even though it is inconsistent with the notion that there is no record of hydrous melting or hydrous metasomatism in the Dramala peridotites based on light element concentrations (Li, Be, B; Pelletier et al., 2008). In this model, the radiogenic Os isotopic character of the Dramala pyroxenites must ultimately be derived from the subducted slab and be carried over a large distance towards the mantle wedge. Metasomatized peridotite xenoliths from mantle wedge localities generally have more radiogenic ${ }^{187} \mathrm{Os} /{ }^{188} \mathrm{Os}$ ratios than unmetasomatized mantle (figure 4 ), but there is an inverse relation between ${ }^{187} \mathrm{Os} /{ }^{188} \mathrm{Os}$ and Os concentration, with radiogenic values around 0.15 so far only found in extremely Os depleted $(<0.03 \mathrm{ng} / \mathrm{g})$ mantle wedge peridotites; Such unusual peridotites may have had their Os removed by oxidizing fluids before metasomatism by a slab-derived agent (Widom et al., 2003). Therefore, as emphasized by Righter and coworkers (2002), there is no support in natural mantle rocks for the existence of metasomatic agents in subduc- tion zone settings that carry sufficient Os over large distances to produce pyroxenites with the unique combination of high Os concentrations (1-10 ng/g) and ${ }^{187} \mathrm{Os} /{ }^{188} \mathrm{Os}>0.15$. Moreover, in the case of the Pindos oceanic basin at $170 \mathrm{Ma}$, subducted ocean crust from any of the Neo-Tethyan oceanic domains could not have been older than $60 \mathrm{Ma}$, as the opening of the Neo-Tethys started in the middle-late Triassic in the region. Subducted 60 Ma ocean crust with a realistic bulk ${ }^{187} \mathrm{Re} /{ }^{188} \mathrm{Os}$ ratio of 50 (a typical value for eclogitic oceanic crustal rocks from Dale et al., 2007) could only have attained an ${ }^{187} \mathrm{Os} /{ }^{188} \mathrm{Os}$ ratio of $\sim 0.17-0.18$ at the time of the ophiolite formation. A mixing model between peridotite $(3.3 \mathrm{ng} / \mathrm{g}$ Os with $\left.{ }^{187} \mathrm{Os} /{ }^{188} \mathrm{Os}=0.1250\right)$ and a realistic slab-derived melt or fluid $\left(0.02 \mathrm{ng} / \mathrm{g}\right.$ Os with $\left.{ }^{187} \mathrm{Os} /{ }^{188} \mathrm{Os}=0.16\right)$ cannot explain the composition of the Pindos concordant pyroxenites (figure 5: model A), nor can a model involving a more radiogenic slab component $\left({ }^{187} \mathrm{Os} /{ }^{188} \mathrm{Os}=0.20\right)$ unusually rich in Os $(0.1 \mathrm{ng} / \mathrm{g}$; figure 5 : model B). The formation of the Dramala concordant pyroxenites requires a metasomatic agent with ${ }^{187} \mathrm{Os} /{ }^{188} \mathrm{Os}$ significantly higher than 0.20 , considering that they are formed - in part from peridotite having Os concentrations 100-1000 higher than any realistic source for the fluid or melt. Subducted sediments or basalts need less ageing to arrive at such radiogenic values, given their higher Re/Os ratios, but such rocks are too poor in Os $(<0.01 \mathrm{ng} / \mathrm{g}$; Brandon et al., 2007; Dale et al., 2007; Penniston-Dorland et al., 2012), to be an important source of radiogenic Os in the postulated silica-rich hydrous melt or fluid. Given these constraints, we conclude that a slab origin for the silica-rich metasomatic agent is unlikely for the Dramala case.

In addition, it is crucial that we recognize that there are instances of pyroxenites that have high Os concentrations and an Os radiogenic character in mantle rocks that are not from subduction zone environments. A key example for our discussion is the Totalp massif (Switzerland), a fragment of subcontinental mantle lithosphere exhumed to Tethys ocean floor by rifting before the on-set of subduction in the Tethys domain (e.g., Van Acken et al., 2010). The massif contains websterites that have high Os concentrations $(>1 \mathrm{ng} / \mathrm{g})$ and radiogenic ${ }^{187} \mathrm{Os} /{ }^{188} \mathrm{Os}$ isotope ratios $(>0.15)$. These occur together with garnetbearing clinopyroxenites, often with the websterites forming the margin of the clinopyroxenites. It has recently been shown that the Totalp pyroxenites formed by meltrock reaction (Van Acken et al., 2010). Clearly, the occurrence of pyroxenites very similar to the Dramala pyroxenites within continental mantle rocks from a nonsubduction zone environment points to the existence of a general petrogenetic process that does not necessarily involve a slab-component. The process that we propose below involves the melting of in-situ, pre-existing eclogitic layers within the mantle. This process may operate in continental mantle, in normal oceanic mantle, as well as in mantle wedge environments (e.g., Pearson et al., 1993). We do not rule out that some mantle wedge pyroxenites can form by reaction with a slab-derived component (McInnes et al., 1999; Batanova \& Sobolev, 2000; Righter et al., 2002; Ackerman et al., 2009). However, 
the eclogite model proposed below can also explain the presence of Os-rich, radiogenic pyroxenite in suprasubduction zone mantle without the need to invoke longrange $(>1 \mathrm{~km})$ transport of radiogenic Os by a slabderived fluid/melt.

\subsection{Hybrid pyroxenites and ancient mafic layers}

A petrogenetic model that involves melting of in-situ, geologically old $\left(>_{c} .1 \mathrm{Ga}\right)$, silica-rich layers with moderate to high $\mathrm{Re} / \mathrm{Os}$ ratios (figure 5) meets all the above requirements. A similar model involving eclogite-derived melts has been proposed for continental mantle pyroxenites (Garrido \& Bodinier, 1999; Van Acken et al., 2010). It is supported by results from high-pressure sandwich experiments of peridotite in contact with an eclogitic mafic layer undergoing partial melting (Yaxley \& Green, 1998; Yaxley \& Sobolev, 2007; Mallik \& Dasgupta, 2012). These experiments show that at high pressures $(>2$ $\mathrm{GPa}$ ) partial melts of the mafic layer with high silicaactivities layer react with the enclosing peridotite to form secondary hybrid pyroxenite, consisting of a garnetclinopyroxenite centre with an orthopyroxene-rich zone in contact with unreacted peridotite. This is essentially due to variations in melt/rock ratios, with reactions with low melt/rock ratios at the contact with peridotite producing a relatively refractory orthopyroxene-rich marginal zone (see also Lambart et al., 2012). We propose that the concordant pyroxenite layers are the melting residues of such hybrid pyroxenites formed at high pressure in the upwelling mantle underneath a ridge system (figure 6). With ongoing low-pressure melting, for instance underneath a mid-ocean ridge system, any residue of the mafic layer and the garnet-clinopyroxenite should progressively melt-out or be transformed to peridotite or dunite (Lambart et al., 2012), leaving behind the relatively refractory outer orthopyroxene-rich reaction zone (Yaxley \& Green, 1998). This two-stage process can explain the nature of the mantle layering observed in our study area (figure 2, 6). Based on our observations alone, we cannot rule out that the central silica-rich layers had a felsic or pelitic composition. However, trace element and isotope geochemistry of MORB suggest that mafic lithologies are a common component in the MORB-source region (e.g., Niu et al., 1997; Donnelly et al., 2004), whereas such evidence for felsic or pelitic components is rare. Mafic layers with ages in excess of $c$. $1 \mathrm{Ga}$ can produce melts that are radiogenic enough $\left({ }^{187} \mathrm{Os} /{ }^{188} \mathrm{Os}>\sim 1\right)$ to produce radiogenic pyroxenites by reaction with peridotite, even if these melts carry very little Os. Mafic layers in continental mantle massifs such as Horoman, Ronda, Beni Bousera, and Totalp - thought to represent ancient basaltic cumulates or recycled oceanic crust - have high ${ }^{187} \mathrm{Os} /{ }^{188} \mathrm{Os}$ (0.8-2.3), with Os concentrations of 0.04-0.4 ng/g (Reisberg et al, 1991; Kumar et al., 1996; Saal et al., 2001; Pearson \& Nowell, 2004; Van Acken et al., 2010).

We applied a modified version of the quantitative melt-hybridization model of Sobolev et al. (2008) to show that reaction between melts derived from the com- plete melting of 1-3 Ga old mafic layers, and wall-rock peridotite, followed by melting of the resultant hybrid pyroxenite, can produce the radiogenic composition and high Os concentration of the observed pyroxenite layers in Dramala. The model for the Os evolution of mafic layers in the mantle (table SI-2) is run with starting compositions for the mafic layers resembling aged basalt $\left({ }^{187} \mathrm{Re} /{ }^{188} \mathrm{Os}=240\right)$ or bulk ocean crust $\left({ }^{187} \mathrm{Re} /{ }^{188} \mathrm{Os}=50\right)$. We have also taken the present-day composition of actual typical mafic layers in the Horoman, Beni Bousera peridotite and Totalp massifs as the starting point for the next step. It is subsequently assumed that these layers melt completely at pressures in excess of $2 \mathrm{GPa}(\sim 65 \mathrm{~km}$ depth) underneath the Pindos spreading centre, and that the melt reacts with the wall-rock peridotites to form a hybrid pyroxenite. We use the most simple reaction model, i.e., one of mixing-assimilation of melt and peridotite; such a simple model is not meant to describe the behaviour of the lithophile elements during the reaction, but may, as a first approximation, give an insight in the behaviour of the IPGE such as Os (Sobolev et al., 2008). Different values for the fraction of peridotite-derived Os $\left(\mathrm{X}_{\text {perid }}\right)$ in the hybrid pyroxenite are explored. It is then assumed that both the peridotite and the hybrid pyroxenite undergo further partial decompression melting at lower pressure during upwelling underneath the spreading centre. The melting is modelled as batch melting. The degree of low-pressure melting of the peridotite is fixed at $15 \%$, and different values for the degree of melting of the pyroxenite $\left(\mathrm{F}_{\mathrm{pxt}}\right)$ are explored.

We find that model runs with mafic layers with basaltic or bulk ocean crustal compositions with ages between 1 and $3 \mathrm{Ga}$ give final compositions for the pyroxenite after mid-ocean ridge melting that are similar to some of the Dramala concordant pyroxenites $\left({ }^{187} \mathrm{Os} /{ }^{188} \mathrm{Os}=0.14\right.$ 0.18 , Os 2-3 ng/g). The same applies to models involving mafic layers such as found in Horoman, Beni Bousera and Totalp, which have typical calculated model ages of 0.5-1.3 Ga. In general, the Os concentration constraint requires that the fraction of peridotite-derived $O s$ in the hybrid pyroxenite $\left(\mathrm{X}_{\text {perid }}\right)$ is high, 0.4-0.6, and that the degree of melting of the hybrid pyroxenite is also high, 0.4-0.7. This is in agreement with experimental data suggesting that pyroxenites start to melt at greater depth and melt faster in the MORB-source region than peridotites, due to their lower solidus temperatures and higher melt productivity (Hirschmann \& Stolper, 1996; Pertermann \& Hirschmann, 2003; Kogiso et al., 2004; Sobolev et al., 2008).

However, the model cannot account for those concordant pyroxenites with high Os concentrations of 3-9.4 $\mathrm{ng} / \mathrm{g}$; these high concentrations, in particular those in excess of the typical Primitive Upper Mantle concentrations ( 3.9 ng/g; Becker et al., 2006), probably require precipitation of Os-bearing cumulate phases such as (Os, Ir, Ru)rich alloys from the eclogite-derived melt during the formation of the hybrid pyroxenites. Precipitation of such Os-rich alloys could have been a direct result of the reaction between mafic layer-derived melt with peridotites during the formation of the hybrid pyroxenites at depth. 
Sulfide solubility in silicate melt is sensitive to the degree of polymerization of the melt, and a separate PGE-rich sulfide phase in a silica-rich melt can be dissolved in the silicate melt due to melt depolymerization (Ballhaus et al., 2006) associated with $\mathrm{SiO}_{2}$-loss as a result of the transformation of olivine to orthopyroxene in the reacted peridotite; PGE initially hosted in the sulfide phase can then precipitate as discrete alloy phases (Ballhaus et al., 2006). We propose that this process may scavenge a significant proportion of the PGE from the melted mafic layer.

The variations in ${ }^{187} \mathrm{Os} /{ }^{188} \mathrm{Os}$ isotope ratios that we measured can be explained by variations in peridotite proportions (or, in other words, variations in melt/rock ratios) in the hybrid pyroxenites in the above model. Qualitatively, we observed that the lowest Os isotope ratios are found in the thinner pyroxenites $(\leq 2 \mathrm{~cm}$, table SI-2), suggesting that thinner hybrid pyroxenites contain a larger peridotite proportion.

\section{Conclusions - a veined upper mantle domain}

The proposed petrogenetic model is nearly identical to the recently proposed 'double distillation'-type model for OIB petrogenesis, where it is argued that high-pressure melting of hybrid pyroxenites formed by melt-rock reactions produces the alkalic melt fractions that carry the HIMU (high ${ }^{238} \mathrm{U} /{ }^{204} \mathrm{~Pb}$ ) signature (Hirschmann et al., 2003; Sobolev et al., 2007; 2008; Mallik \& Dasgupta, 2012). Estimates for the ${ }^{187} \mathrm{Os} /{ }^{188}$ Os composition of the HIMU component in the mantle source are 0.14-0.16 (Reisberg et al., 1993; Hauri \& Hart, 1993; Lassiter et al., 2000). Our data show that pyroxenite layers with such radiogenic Os isotope compositions do indeed exist on a $<10 \mathrm{~cm}$ scale in the upper mantle, and that they can in part be preserved in highly refractory mantle rocks that have seen extensive melting and late-stage meltpercolation at an oceanic spreading centre.

Concordant pyroxenites in the Dramala Complex are very abundant in the km-scale study area, with typically at least one pyroxenite present in a metre-long section, but they are much rarer or absent in other areas in the same massif. If each of the concordant pyroxenites represents the refractory reacted wall rock of a melted eclogitic layer, then eclogitic layers were locally abundant in the oceanic mantle source rock before melting. A simple budget estimation suggests that each concordant hybrid pyroxenite with $>1 \mathrm{ng} / \mathrm{g}$ Os containing a $50 \%$ contribution of Os from an eclogite precursor (as in the numerical model outlined above) must have concentrated the Os from a typical eclogite layer with $\leq 0.1 \mathrm{ng} / \mathrm{g}$ Os that was one order of magnitude thicker than the final hybrid pyroxenite. This suggests that a typical precursor eclogite layer with symmetrical hybrid pyroxenite margins had a thickness of 0.5-2 m. We conclude that the Dramala pyroxenite layers are the final melting residue of metrescale, billion-year old 'eclogitic' veins in a kilometrescale marble cake domain in the oceanic mantle. The Dramala Complex may represent the melting residue of a mantle domain containing recycled ocean crust (Hofmann \& White, 1982; Allègre \& Turcotte, 1986; Morishita et al., 2004) or of a raft of continental mantle lithosphere stranded in the oceanic mantle after continental break-up (Coltorti et al., 2010). The preservation of abundant billion-year old lithological layers in the oceanic mantle suggests that mechanical mixing in the convecting mantle is ineffective even over long time-scales.

\section{Acknowledgements}

We thank A. Kalt, O. Müntener, S. Pilet, and A. Ulianov for critical discussions and reading of the manuscript. Constructive comments by D. Van Acken and C. Garrido improved the manuscript considerably. We also acknowledge comments on an earlier version of the paper by A. Sobolev, J. Lassiter and an anonymous reviewer. These results were obtained as part of a research project awarded to A.H.D. by the Swiss National Science Foundation (SNF). D.S.S. acknowledges a doctorate student fellowship by the SNF, and mobility grants from the Ecole Doctorale en Sciences des Minéraux (EDSM).

\section{Appendix A. Supplementary data}

Supplementary data (tables SI-1 and SI-2, figures SI1 and SI-2) and a KML-file with sample locations can be found online at

http://dx.doi.org/10.1016/j.eps1.2013.10.039.

\section{References}

Ackerman, L., Jelinek, E., Medaris Jr., G., Jezek, J., Siebel, W. \& Strnad, L., 2009. Geochemistry of Fe-rich peridotites and associated pyroxenites from Horní Bory, Bohemian Massif: Insights into subduction-related melt-rock reactions. Chemical Geology 259, 152-167.

Allègre, C.J. \& Turcotte D.L., 1986. Implications of a twocomponent marble-cake mantle. Nature 323, 123-127.

Anders, E., Grevesse, N., 1989. Abundances of the elements: meteoric and solar. Geochimica et Cosmochimica Acta 53, 197-214.

Ballhaus, C., Bockrath, C., Wohlgemuth-Ueberwasser, C., Laurenz, V. \& Berndt, J., 2006. Fractionation of the noble metals by physical processes. Contrib. Mineral. Petrol. 152, 667-684.

Batanova, V.G. \& Sobolev, A.V., 2000. Compositional heterogeneity in subduction-related mantle peridotites, Troodos massif, Cyprus. Geology 28, 55- 58.

Becker, H., Horan, M.F., Walker, R.J., Gao, S., Lorand, J-P. and Rudnick, R.L., 2006. Highly siderophile element composition of the Earth's primitive upper mantle: Constraints from new data on peridotite massifs and xenoliths. Geochimica et Cosmochimica Acta 70, 4528-4550.

Berly, T.J., Hermann, J., Arculus, R.J., \& Lapierre, H., 2006. Supra-subduction zone pyroxenites from San Jorge and Santa Isabel (Solomon Islands). J. Petrol. 47, 1531-1555.

Birck, J.L., Roy-Barman, M., \& Campas, F., 1997. Re-Os isotopic measurements at the femtomole level in natural samples, Geostandards Lett. 20, 19-27.

Bodinier, J.-L., Garrido, C.J., Chanefo, I., Brughier, O., \& Gervilla, F., 2008. Origin of pyroxenites-peridotite veined mantle by refertilization reactions: Evidence from the Ronda Peridotite (Southern Spain). J. Petrol. 49, 999-1025. 
Bockrath, C., Ballhaus, C. \& Holzheid, A., 2004. Fractionation of the Platinum-Group Elements during mantle melting. Science 305, 1951-1953.

Blichert-Toft, J., Albarède, F. \& Kornprobst, J., 1999. Lu-Hf isotope systematics of garnet pyroxenites from Beni Bousera, Morocco: Implications for basalt origin. Science 283, 1303-1306.

Brandon, A.D., Creaser, R.A., Shirey, S.B., \& Carlson, R.W., 1996. Osmium recycling in subduction zones. Science 272, 861-864.

Brandon, A.D., Graham, D.W., Waight, T. \& Gautason, B., 2007. ${ }^{186} \mathrm{Os}$ and ${ }^{187} \mathrm{Os}$ enrichments and high- ${ }^{3} \mathrm{He} /{ }^{4} \mathrm{He}$ sources in the Earth's mantle: Evidence from Icelandic picrites. Geochimica et Cosmochimica Acta 71, 4570-4591.

Brenker, F.E., Meibom, A. \& Frei, R., 2003. On the formation of peridotite-derived Os-rich PGE alloys. Am. Mineral. 88, 1731-1740.

Büchl, A., G. Brügmann, \& V.G. Batanova., 2004. Formation of podiform chromite deposits: implications from PGE abundances and Os isotopic compositions of chromites from the Troodos complex, Cyprus. Chem. Geol. 208, 217-232.

Büchl, A., G. Brügmann, V.G. Batanova, C. Münker, A.W. Hofmann., 2002. Melt percolation monitored by Os isotopes and HSE abundances: A case study from the mantle section of the Troodos Ophiolite. Earth Planet. Sci. Lett. 204, 385402.

Burg, J-P., Bodinier, J-L., Chaudry, S., Hussain, S., \& Dawood, H., 1998. Infra-arc mantle-crust transition and intra-arc mantle diapirs in the Kohistan Complex (Pakinstani Himalaya): petro-structural evidence. Terra Nova 10, 74-80.

Ceuleneer, G. \& Rabinowicz, M., 1992. Mantle flow and melt migration beneath oceanic ridges: Models derived from observations in ophiolites. In: Mantle flow and melt generation at mid-ocean ridges, AGU Geophys. Monogr. 71, 123-154.

Coltorti, M., Bonadiman, C., O’Reilly, S.Y., Griffin, W.L., \& Pearson, N.J., 2010. Buoyant ancient continental mantle embedded in oceanic lithosphere (Sal Island, Cape Verde Archipelago). Lithos 120, 223-233.

Dale, C.W., Gannoun, A., Burton, K.W., Argles, T.W., \& Parkinson I.J., 2007. Rhenium-osmium isotope and elemental behaviour during subduction of oceanic crust and the implications for mantle recycling. Earth. Plan. Sci. Lett. 253, 211-225.

Dantas, C., Ceuleneer, G., Gregoire, M., Python, M., Freydier, R., Warren, J., \& Dick, H.J.B., 2007. Pyroxenites from the Southwest Indian Ridge, 9-16 ${ }^{\circ} \mathrm{E}$ : Cumulates from Incremental Melt Fractions Produced at the Top of a Cold Melting Regime. J. Petrol. 48 (4), 647-660.

Dhuime, B., Bosch, D., Bodinier, J-L., Garrido, C.J., Bruguier, O., Hussain, S.S. \& Dawood, H., 2007. Multistage evolution of the Jijal ultramafic-mafic complex (Kohistan, N Pakistan): Implications for building the roots of island arcs. Earth and Planetary Science Letters 261, 179-200.

Dijkstra, A.H., Sergeev, D.S., Spandler, C., Pettke, T., Meisel, T., \& Cawood, P.A., 2010. Highly refractory peridotites on Macquarie Island and the case for anciently depleted domains in the Earth's mantle. J. Petrol. 51, 469-493.

Donnelly, K.E., Goldstein, S.L., Langmuir, C.H., \& Spiegelman, M., 2004. Origin of enriched ocean ridge basalt and implications for mantle dynamics. Earth Planet. Sci. Lett. 226, 347-366.

Downes, H., 2007. Origin and significance of spinel and garnet pyroxenites in the shallow lithospheric mantle: Ultramafic massifs in orogenic belts in Western Europe and NW Africa. Lithos 99, 1-24.

Garrido, C.J. \& Bodinier, J-L., 1999. Diversity of mafic rocks in the Ronda Peridotites: Evidence for pervasive melt-rock re- action during heating of subcontinental lithosphere by upwelling mantle. J. Petrol. 40, 729-754.

Garrido, C.J., Bodinier, J-L., Dhuime, B., Bosch, D., Chanefo, I., Bruguier, O., Hussain, S.S., Dawood, H. \& Burg, J.P., 2007. Origin of the island arc Moho transition zone via melt-rock reaction and its implications for intracrustal differentiation of island arcs: Evidence from the Jijal complex (Kohistan complex, northern Pakistan). Geology 35, 683686.

Handler, A.R., Wysiczanski, R.J., \& Gamble, J.A., 2003. Proterozoic lithsphere in Marie Byrd Land, West Antarctica: ReOs systematics of spinel peridotite xenoliths. Chem. Geol. 196, 131-145.

Harvey, J., Gannoun, A., Burton, K.W., Rogers, N.W., Alard, O., \& Parkinson, I.J., 2006. Ancient melt extraction from the oceanic mantle revealed by Re-Os isotopes in abyssal peridotites from the Mid-Atlantic ridge. Earth Planet. Sci. Lett. 244, 606-621.

Hassler, D.R., Peucker-Ehrenbrink, B. \& Ravissa, G., 2000. Rapid determination of Os isotopic composition by sparging $\mathrm{OsO}_{4}$ into a magnetic-sector ICP-MS. Chemical Geology $166,1-14$.

Hauri, E.H. \& Hart, S.R., 1993. Re-Os isotope systematics of HIMU and EMII oceanic island basalts from the south Pacific Ocean. Earth Planet. Sci. Lett. 114, 353-371.

Hellebrand E., Snow J.E., Dick H.J. B. \& Hofmann A.W., 2001. Coupled major and trace elements as indicators of the extent of melting in mid-ocean-ridge peridotites. Nature 410. 677681.

Hirschmann, M.M. \& Stolper, E.M., 1996. A possible role for garnet pyroxenite in the origin of the "garnet signature" in MORB. Contrib. Mineral. Petrol. 124, 185-208.

Hirschmann, M.M., Kogiso, T., Baker, M.B., \& Stolper, E.M., 2003. Alkalic magmas generated by partial melting of garnet pyroxenite. Geology 31, 481-484.

Hofmann, A.W., 1997. Mantle geochemistry: the message from oceanic volcanism. Nature 385, 219-229.

Hofmann, A.W. \& White, W.M., 1982. Mantle plumes from ancient oceanic crust. Earth Plan. Sci. Lett. 57, 421-436.

Jacob, D.E., Bizimis, M., \& Salters, V.J.M., 2005. Lu-Hf and geochemical systematics of recycled ancient ocean crust: Evidence from Roberts Victor eclogites. Contrib. Mineral. Petrol. 148, 707-720.

Jones, G., Robertson, A.H.F., \& Cann, J.R., 1991. Genesis and emplacement of the supra-subduction zone Pindos Ophiolite, Northwestern Greece. In: Peters, Tj. et al. (eds.) Ophiolite genesis and evolution of the oceanic lithosphere. Kluwer Academic Publishers, Dordrecht/Boston, 771-799.

Kelemen, P.B., Dick, H.J.B., \& Quick, J.E., 1992. Formation of harzburgite by pervasive melt/rock reaction in the upper mantle. Nature 358, 635-641.

Kelemen P.B., Hart, S.R., \& Bernstein, S., 1998. Silica enrichment in the continental upper mantle via melt/rock reaction. Earth Planet. Sci. Lett. 164, 387-406.

Kogiso, T., Hirschmann, M.M. \& Pertermann, M., 2004. Highpressure partial melting of mafic lithologies in the mantle. J. Petrol. 45, 2407-2422.

Kumar, N., Reisberg, L. \& Zindler, A., 1996. A major and trace element and strontium, neodymium, and osmium isotopic study of a thick pyroxenite layer from the Beni Bousera Ultramafic Complex of northern Morocco. Geochim. Cosmochim. Acta 60, 1429-1444.

Lambart, S., LaPorte, D., Provost, A. \& Schiano, P., 2012. Fate of pyroxenite-derived melts in the peridotitic mantle: thermodynamic and experimental constraints. J. Petrol. 53 (3), 451-476. 
Lassiter, J.C., Hauri, E.H., Reiners, P.W., \& Garcia, M.O., 2000. Generation of Hawaiian post-erosional lavas by melting of a mixed lherzolites/pyroxenites source. Earth Plan. Sci. Lett. 178, 269-284.

Liati, A., Gebauer, D., \& M.C. Fanning., 2004. The age of ophiolitic rocks of the Hellenides (Vourinos, Pindos, Crete): first U-Pb ion microprobe (SHRIMP) zircon ages. Chem. Geol. 207, 171-188.

Liu, C-Z., Snow, J.E., Hellebrand, E., Brügmann, G., von der Handt, A., Büchl, A., \& Hofmann, A., 2008. Ancient, highly heterogeneous mantle beneath Gakkel ridge, Arctic Ocean. Nature 452, 311-316.

Mallik, A. \& Dasgupta, R., 2012. Reaction between MORBeclogite derived melts and fertile peridotite and generation of ocean island basalts. Earth and Planetary Science Letters 329-330, 97-108.

Marchesi, C., Garrido, C.J., Bosch, D., Bodinier, J-L., Gervilla, F. \& Hidas, K., 2013. Mantle refertilization by melts of crustal-derived garnet pyroxenite: Evidence from the Ronda peridotite massif, southern Spain. Earth Planet. Sci. Lett. $362,66-75$

Meibom, A., Sleep, N.H., Chamberlain, C.P., Coleman, R.G., Frei, R., Hren, M.T. \& Wooden, J.L., 2002. Re-Os isotopic evidence for long-lived heterogeneity and equilibration processes in the Earth's upper mantle. Nature 419, 705-708.

Meibom, A., Frei, R. \& Sleep, N.H., 2004. Osmium isotopic compositions of Os-rich platinum group element alloys from the Klamath and Siskiyou Mountains. J. Geoph. Res. B109, doi:10.1029/2003JB002602

McInnes, B.I.A., McBride, J.S., Evans, N.J., Lambert, D.D., \& Andrew, A.S., 1999. Osmium isotope constraints on ore metal recycling in subduction zones. Science 286, 512-516.

Meisel T., R.J. Walker, \& J.W. Morgan J.W., 1996. The osmium isotopic composition of the Earth's primitive upper mantle. Nature 383, 517-520.

Meisel, T., Fellner, N., and Moser, J., 2003. A simple procedure for the determination of platinum group elements and rhenium ( $\mathrm{Ru}, \mathrm{Rh}, \mathrm{Pd}, \mathrm{Re}, \mathrm{Os}$, Ir and $\mathrm{Pt}$ ) using ID-ICP-MS with an inexpensive on-line matrix separation in geological and environmental materials, J. Anal. At. Spectrom., 18, 720726.

Montanini, A., Tribuzio, R. \& Thirlwall, M., 2012. Garnet clinopyroxenite layers from the mantle sequences of the Northern Appennine ophiolites (Italy): Evidence for recycling of crustal material. Earth and Planetary Science Letters 351-352, 171-181.

Morishita, T., Arai, S. \& Green, D., 2004. Possible non-melted remnants of subducted lithosphere: Experimental and geochemical evidence from corundum-bearing mafic rocks in the Horoman Peridotite Complex, Japan. J. Petrol. 45, 235252.

Niu, Y. \& Batiza, R., 1997. Trace element evidence from seamounts for recycled oceanic crust in the Eastern Pacific mantle. Earth Plan. Sci. Lett. 148, 471-483.

Pe-Piper, G., and Piper D.J.W., 2002. The igneous rocks of Greece. The anatomy of an orogen. Gebrüder Borntraeger, Berlin.

Pe-Piper, G., Tsikouras, B. \& Hatzipanagiotou, K., 2004. Evolution of boninites and island-arc tholeiites in the Pindos Ophiolite, Greece. Geological Magazine 141 (4), 455-469.

Pearson, D.G. \& Nowell, G.M., 2004. Re-Os and Lu-Hf isotope constraints on the origin and age of pyroxenites from the Beni Bousera Peridotite Massif: Implications for mixed peridotite-pyroxenite mantle sources. J. Petrol. 45, 439-455.

Pearson, D.G., Davies, G.R. \& Nixon, P.H., 1993. Geochemical constraints on the petrogenesis of diamond facies pyroxe- nites from the Beni Bousera Peridotite Massif, North Morocco. J. Petrol. 34, 125-172.

Pearson, D.G., Irvine, G.J., Ionov, D.A., Boyd, F.R. \& Dreibus, G.E., 2004. Re-Os isotope systematics and platinum group element fractionation during mantle melt extraction: a study of massif and xenolith peridotite suites. Chem. Geol. 208, 29-59.

Pearson, D.G., Parman, S.W. \& Nowell, G.M., 2007. A link between large mantle melting events and continent growth seen in osmium isotopes. Nature 449, 202-204.

Pelletier, L., Vils. F., Kalt, A. \& Gméling, K., 2008. Li, B, and $\mathrm{Be}$ contents of harzburgites from the Dramala Complex (Pindos ophiolite, Greece): a MOR-type mantle in a suprasubduction zone environment. J. Petrol. 49, 2043-2080.

Penniston-Dorland, S.C., Walker, R.J., Pitcher, L. \& Sorensen, S.S., 2012. Mantle-crust interactions in a paleosubduction zone: Evidence from highly siderophile element systematics of eclogite and related rocks. Earth Planet. Sci. Lett. 319, 295-306.

Pertermann, M. \& Hirschmann, M.M., 2003. Anhydrous partial melting experiments on MORB-like eclogite: Phase relations, phase compositions and mineral-melt partitioning of major elements at 2-3 GPa. J. Petrol. 44 (12), 2173-2201.

Rassios, A. \& Grivias, E., c. 2007. 1:100,000 geological and metallogenic map of the Pindos imbricated ophiolite and associated units. IGME, Kozani, Greece.

Rassios, A.E.H. \& Moores, E.M., 2006. Heterogeneous mantle complex, crustal processes, and obduction kinematics in a unified Pindos-Vourinos ophiolitic slab (northern Greece). Geol. Soc. Lond. Spec. Publ. 260, 237-266.

Rehkamper M., Halliday A.N., Barfod D., \& Fitton J.G., 1997. Platinum-group element abundance pattern in different mantle environments. Science 278, 1595-1598.

Reisberg, L., Allègre, C. J. \& Luck, J.M., 1991. The Re-Os systematics of the Ronda ultramafic complex in southern Spain. Earth Planet. Sci. Lett. 105, 196-213.

Reisberg, L., Zindler, A., Marcantonio, F., White, W., Wyman, D., \& Weaver, B., 1993. Os isotope systematics in ocean island basalts. Earth. Plan. Sci. Letters 120, 149-167.

Righter, K., Chesley, J.T., \& Ruiz, J., 2002. Genesis of primitive, arc-type basalt: Constraints from $\mathrm{Re}, \mathrm{Os}$, and $\mathrm{Cl}$ on depth of melting and role of fluids. Geology 30, 619-622.

Saal, A.E., Takazawa, E., Frey, F.A., Shimizu, N. \& Hart, S.R., 2001. Re-Os isotope in the Horoman peridotite: evidence for refertilisation? J. Petrol. 42, 25-37.

Saccani,E. \& Photiades, A., 2004. Mid-ocean ridge and suprasubduction affinities in the Pindos ophiolites (Greece): implications for magma genesis in a fore-arc setting. Lithos 73, 229-253.

Saha, A., Basu, A.R., Jacobsen, S.B., Poreda, R.J., Yin, Q.-Z., \& Yogodzinski, G.M., 2005. Slab devolatilization and Os and $\mathrm{Pb}$ mobility in the mantle wedge of the Kamchatka arc. Earth. Plan. Sci. Lett. 236, 182-194.

Smith, A.G., 1993. Tectonic significance of the HellenicDinaric ophiolites. in: Prichard, H. M., Alabaster, T., Harris, N. B. W. \& Neary, C. R. (eds), Magmatic Processes and Plate Tectonics, Geological Society Special Publication No. 76, 213-243.

Sobolev, A.V., Hofmann, A.W., Brügmann, G., Batanova, V.G., Kuzmin, D.V., 2008. A quantitative link between recycling and Osmium isotopes. Science 321, 536.

Sobolev, A.V. et al., 2007. The amount of recycled crust in the sources of mantle-derived melts. Science 316, 412-417.

Smoliar M. I., Walker R. J. \& Morgan J. W., 1996. Re-Os isotope constraints on the age of Group IIA, IIIA, IVA, and IVB iron meteorites. Science 271, 1099-1102. 
Van Acken, D., Becker, H., Walker, R.J., McDonough, W.F., Wombacher, F., Ash, R.D., \& Piccoli, P.M., 2010. Formation of pyroxenites layers in the Totalp ultramafic massif (Swiss Alps) - Insights from highly siderophile elements and Os isotopes. Geochim. Cosmochim. Acta 74, 661-683.

Walker, R.J., Prichard, H.M., Ishiwatari, A. \& Pimentel, M., 2002. The Osmium isotopic composition of convecting upper mantle deduced from ophiolite chromites. Geochim. Cosmochim. Acta 66, 329-345.
Widom, E., Kepezhinskas, P., \& Defant, M., 2003. The Nature of metasomatism in the sub-arc mantle wedge: Evidence from Re-Os isotopes in Kamchatka peridotite xenoliths. Chem. Geol. 196, 283-306.

Yaxley, G.M. \& Green, D.H., 1998. Reactions between eclogite and peridotite: mantle refertilization by subduction of oceanic crust. Schweiz. Mineral. Petrogr. Mitt. 78, 243-255.

Yaxley, G.M. \& Sobolev, A.V., 2007. High-pressure partial melting of gabbro and its role in the Hawaiian magma source. Contrib. Mineral. Petrol. 154, 371-383. 
Figure 1. Regional geology of the Pindos Ophiolite. A. Section across the Pindos Ophiolite, showing the Dramala Complex thrust sheet overlying the Aspropotamos Complex thrust sheet, with the tectonic contact marked by metamorphic sole rocks. The Dramala Complex has a Mid-Ocean Ridge (MOR), whereas the Aspropotamos has a SupraSubduction Zone (SSZ) character. Approximate structural position of the mantle layering domain discussed in the text is also shown. Figure modified from Rassios and Moores (2006). B. Geological map of the northern part of the Dramala Massif in the Valia Kalda National Park, based on our own mapping and on the 1:100,000 map of the Pindos Ophiolite by Rassios \& Grivas (c. 2007). Map shows sample locations and the traces of foliations in mylonite, fine-grained tectonite and coarse-grained tectonites (terminology of Ceuleneer \& Rabinowicz, 1992) that we mapped in blue, purple and red respectively. The study area with coarse-grained peridotite tectonites and prominent mantle layering is marked by the circle. Roads/tracks and UTM coordinates (WGS'84 and Greek Map Datum GGRS - EGSA87) are from 1:50,000 topographic map, Valia Kalda sheet (Anavasi Publishers, Athens, 2006). See also KML file with sample coordinates in supplementary information.

Figure 2. Mantle layering in the Dramala Complex. A-B. Field aspect of mantle layering parallel to the S to SWdipping tectonite foliation (dashed white line) described in the text. Pyroxenite layers are denoted with 'pxt'; note the set of four closely-spaced parallel (transposed) pyroxenites and the thicker pyroxene-poor harzburgite above them in panel A. C. Field aspect of mantle layering with thin pyroxenites, cross-cut by two thin, late-stage cumulate pyroxenites. D. Photomicrograph in crossed-polarized light of interior part of a concordant pyroxenite layer, showing orthopyroxene crystals (in shades of grey and pale brown) containing inclusions of clinopyroxene with nearly identical crystallographic orientations, a so-called orientation family (marked with white arrows).

Figure 3. Highly Siderophile Element (HSE) concentrations and Os isotope ratios of the studied samples. A. HSE concentrations, normalized to CI chondrite (Anders \& Grevese, 1989), in concordant pyroxenite samples. B. Normalized HSE concentrations in peridotites and in cross-cutting pyroxenite dykes. C, Present-day measured ${ }^{187} \mathrm{Os} /{ }^{188} \mathrm{Os}$ isotope ratios versus $\mathrm{SiO}_{2} / \mathrm{MgO}$ (indicative of pyroxene content) in whole rock samples of peridotite and pyroxenite. D. Present-day measured ${ }^{187} \mathrm{Os} /{ }^{188}$ Os isotope ratios versus Os whole rock concentration in peridotite and pyroxenite samples. Grey bar in $\mathrm{C}$ and $\mathrm{D}$ corresponds to the range of Os isotope ratios found in Mesozoic ophiolitic chromitites (Walker et al., 2002). Red cross indicates values for present-day Primitive Upper Mantle (Meisel et al., 1996). Black error bars in $\mathrm{C}$ and $\mathrm{D}$ indicate typical total uncertainties.

Figure 4. A. Os concentrations and ${ }^{187} \mathrm{Os} /{ }^{188} \mathrm{Os}$ ratios of Dramala pyroxenites and peridotites, compared to metasomatized mantle wedge peridotites and continental mantle pyroxenites. Mantle wedge peridotites and continental pyroxenites show very different trends originating at a common peridotitic source, as indicated by the pink arrows. Also shown are eclogitic $160 \mathrm{Ma}$ oceanic gabbros and basalts (Dale et al., 2007), and pyroxenites from continental mantle massifs formed by reaction between peridotite and eclogite-derived melt (Reisberg et al., 1991; Bodinier et al., 2008; Van Acken et al., 2010). Model curves with age labels represent typical 0-4000 Ma bulk ocean crust $\left({ }^{187} \mathrm{Re} /{ }^{188} \mathrm{Os}=50\right.$, $\left.[\mathrm{Os}]_{\text {init }}=0.023 \mathrm{ng} / \mathrm{g}\right)$ and MORB $\left({ }^{187} \mathrm{Re} /{ }^{188} \mathrm{Os}=240,[\mathrm{Os}]_{\text {init }}=0.0086 \mathrm{ng} / \mathrm{g}\right.$; values from Brandon et al., 2007) at $170 \mathrm{Ma}$. Data for mantle wedge xenoliths from Brandon et al. (1996), McInnes et al. (1999), Widom et al. (2003), Handler et al. (2003) and Saha et al. (2005).

Figure 5. Results of simple mixing-assimilation modeling between peridotite and slab-derived melts/fluids or melts from complete melting of ancient mafic layer from Horoman, compared to Os (isotopic) compositions of peridotites and pyroxenites from the Dramala Complex. Outcomes of other models involving ancient mafic layers are given in table SI-2. PUM is Primitive Upper Mantle composition of Becker et al. (2006). Ticks on curves represent fraction of peridotite in the mix $(0<$ Xperid $<1)$. Grey areas to the left of the curves represent residues of up to $50 \%(\mathrm{~F}=0.5)$ batch melting of modeled mixtures. Models and parameters discussed in the text. Slab-derived fluids or hydrous melts are not radiogenic enough and carry only little Os and are unlikely sources of radiogenic Os in the Dramala concordant pyroxenites. In contrast, melts derived from geologically old $(>c .1 \mathrm{Ga})$ mafic layers in continental mantle massifs (e.g., Horoman) are much more radiogenic, and only relatively small fractions of such melt are required to explain the radiogenic isotope signatures and mantle-like Os concentrations in reaction-type pyroxenites. Inset diagram on top right shows enlargement of the most relevant part of the diagram, for Os concentrations between $1-10 \mathrm{ng} / \mathrm{g}$, and1870s/1880 $\mathrm{s}=0.12-0.22$, for the case involving the melting of a mafic layer from Horoman. Horizontal dashed lines are for different values (0.4-1.0) of the peridotite fraction in the hybrid pyroxenite (Xperid) formed by the reaction between peridotite and melt derived from the mafic layer, whereas curved steep lines are for different values of the subsequent degree of melting $(0<\mathrm{F}<1.0)$ of the hybrid pyroxenite at low pressure.

Figure 6. Petrogenetic model for the formation of the mantle layering, including the inferred grain-scale textural evolution. Billion-year old mafic layers (in red) melted at depth underneath the Mesozoic Pindos spreading center. Silicarich melts reacted with wall-rock peridotite (in dark green) to form secondary hybrid pyroxenite reaction zones (bright 
green and grey). The thus formed hybrid pyroxenite melted in the MORB-source region at depths $<65 \mathrm{~km}$ together with peridotite to form MORB. In the melting column, percolation of melts caused pyroxene-dissolving melt-rock reactions, eventually leading to a mantle layering consisting of dunite (in orange), harzburgite with varying modal pyroxene proportions, and relic concordant pyroxenite layers. Wiggly arrows indicate melt percolation; white circles represent melting. 


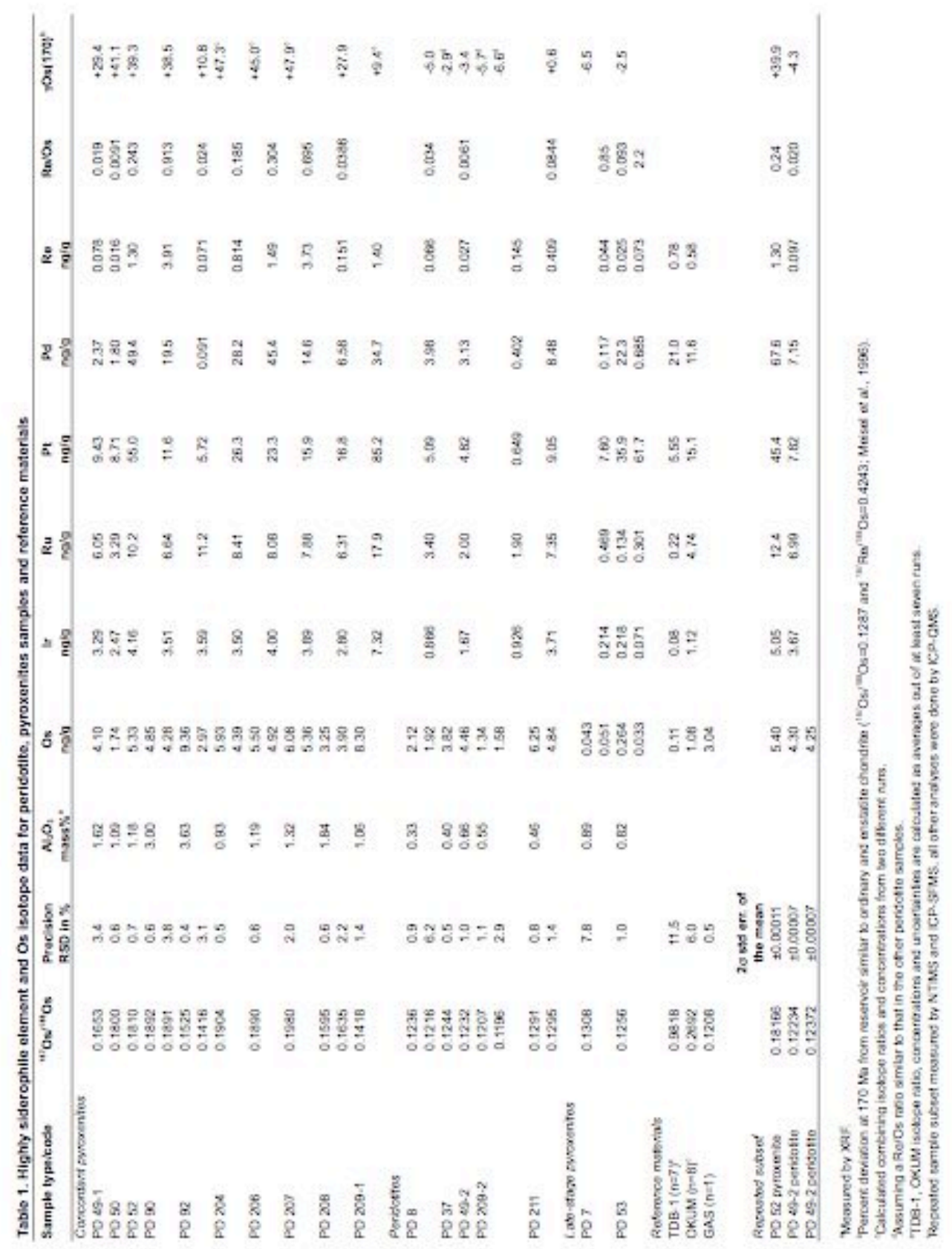




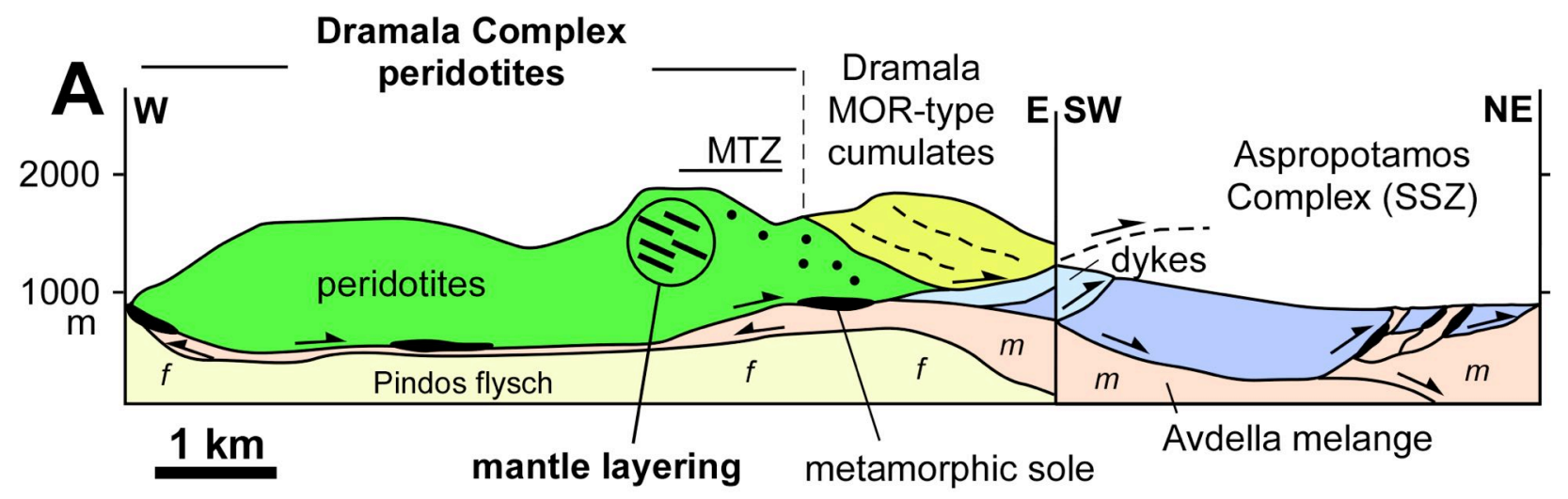

B

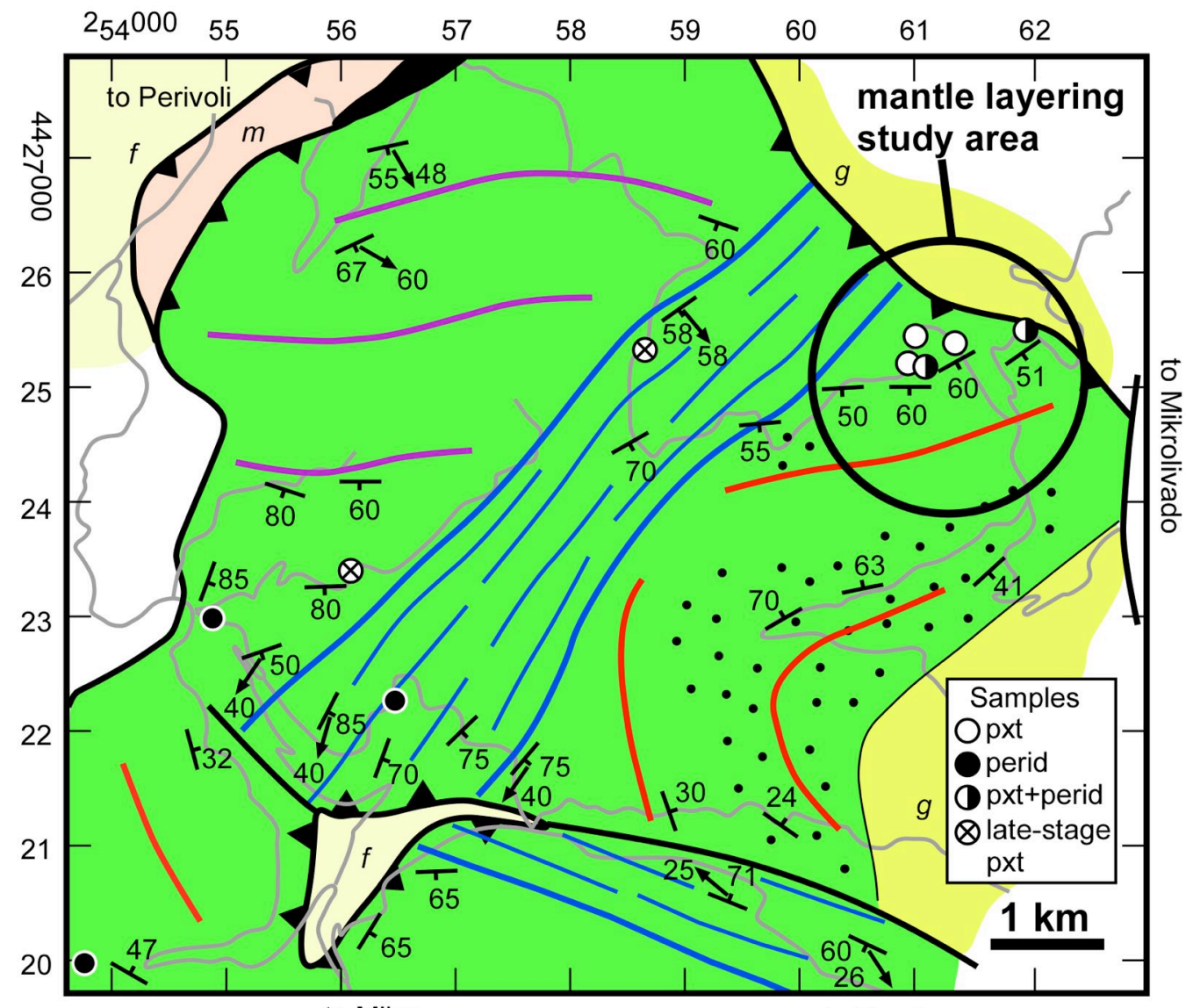

to Milea

to Krania
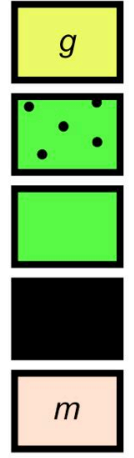

$f$

Cumulate gabbro (mostly troctolite)

Plagioclase-Iherzolite with gabbro dykes and veins Peridotite (mostly harzburgite)

Banded amphibolite ('metamorphic sole') Ophiolitic mélange Flysch Fault

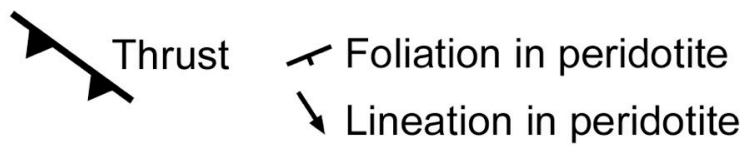

Peridotite mylonite shearzone Trace of foliation in fine-grained recrystallized tectonite Trace of foliation in coarse-grained tectonite

figure 1 

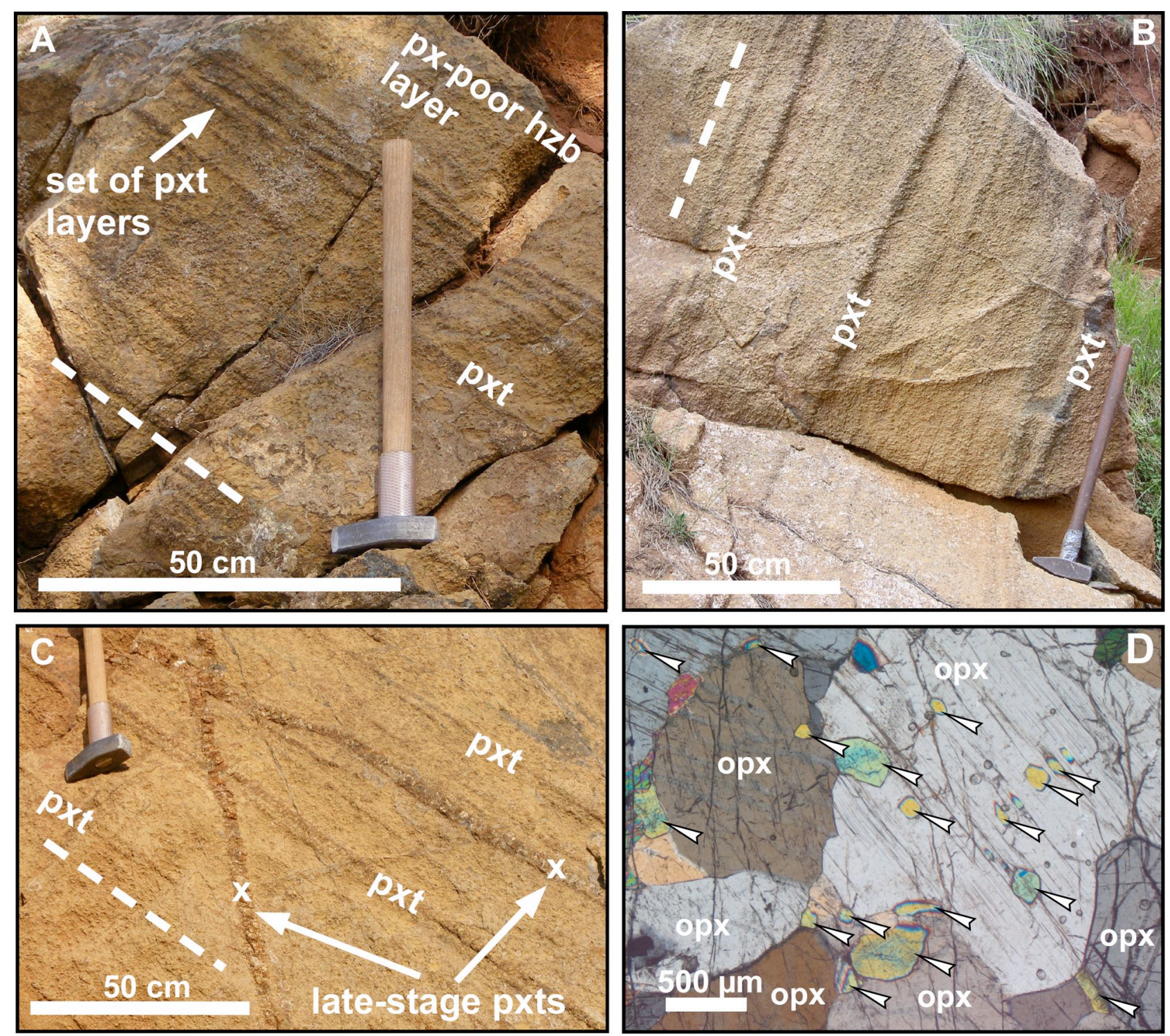

figure 2 

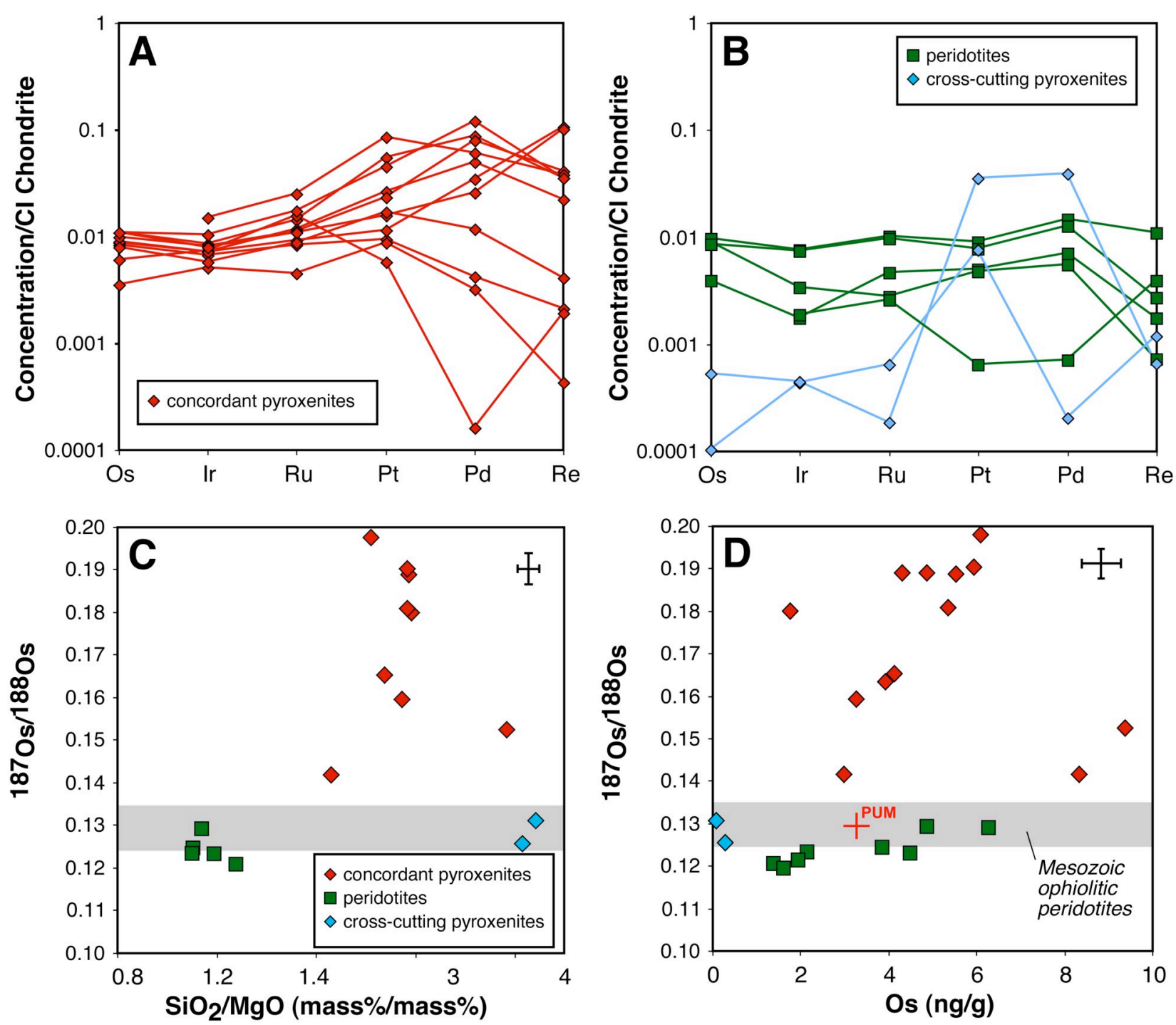

figure 3 


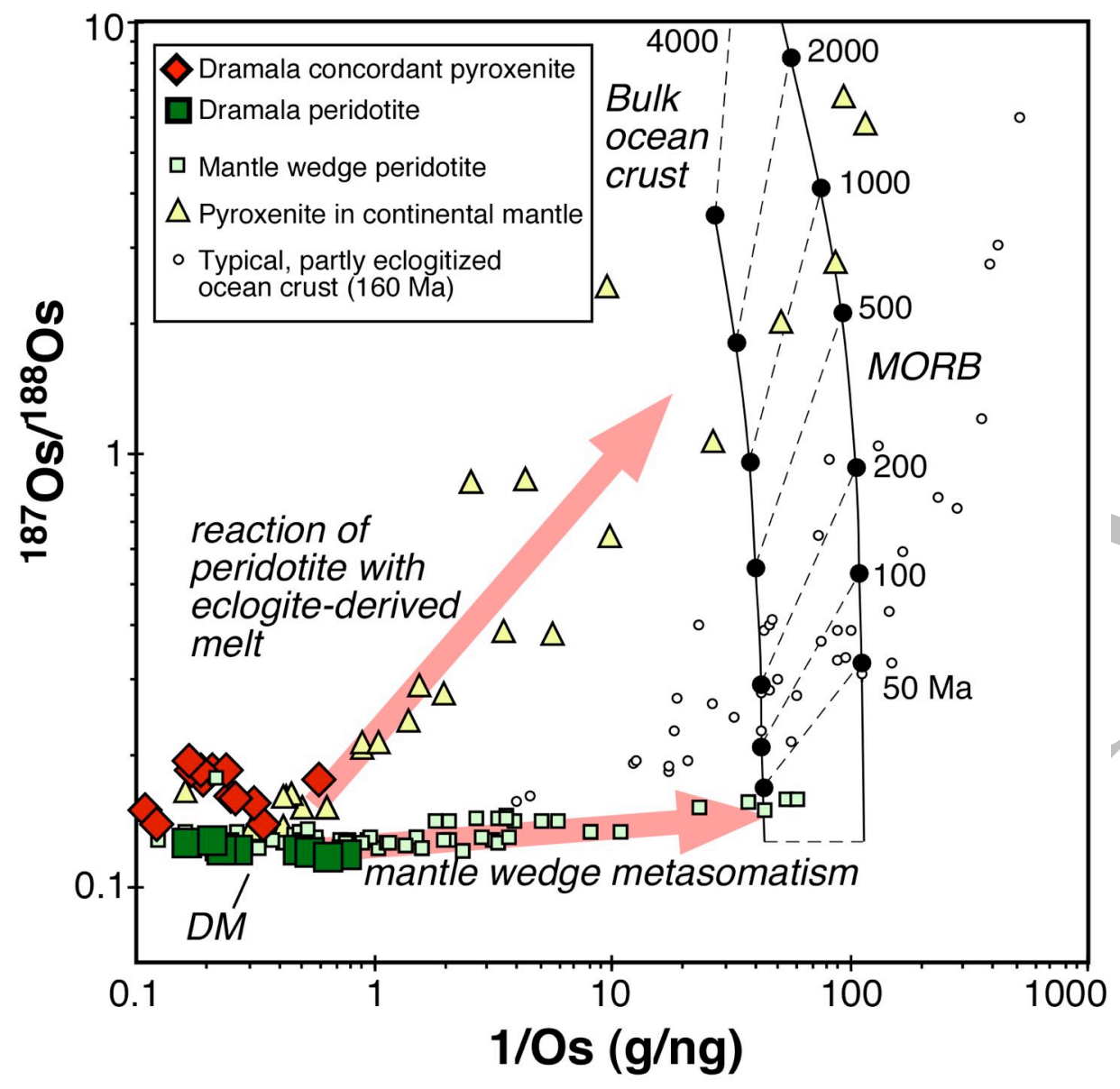

figure 4 


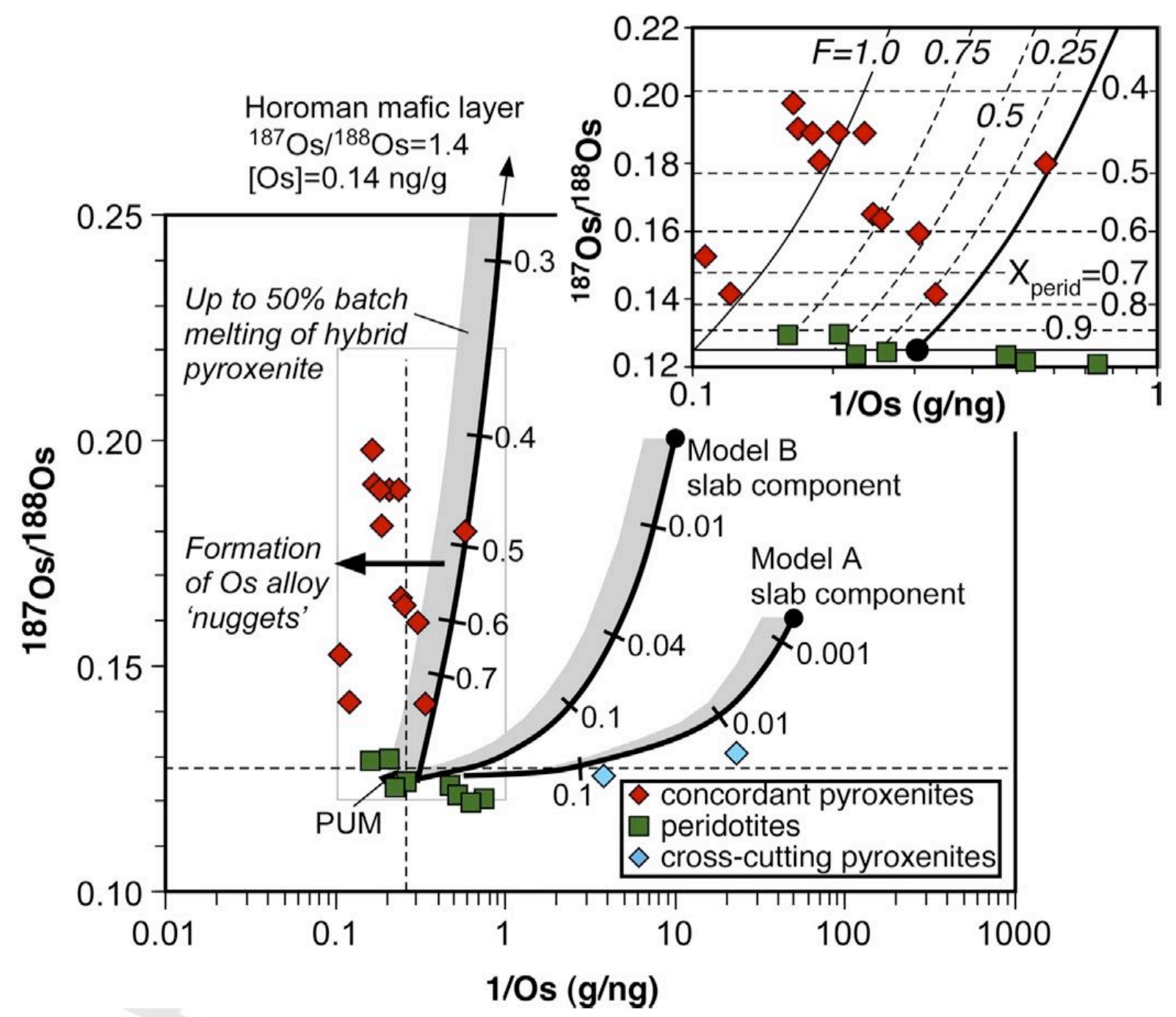




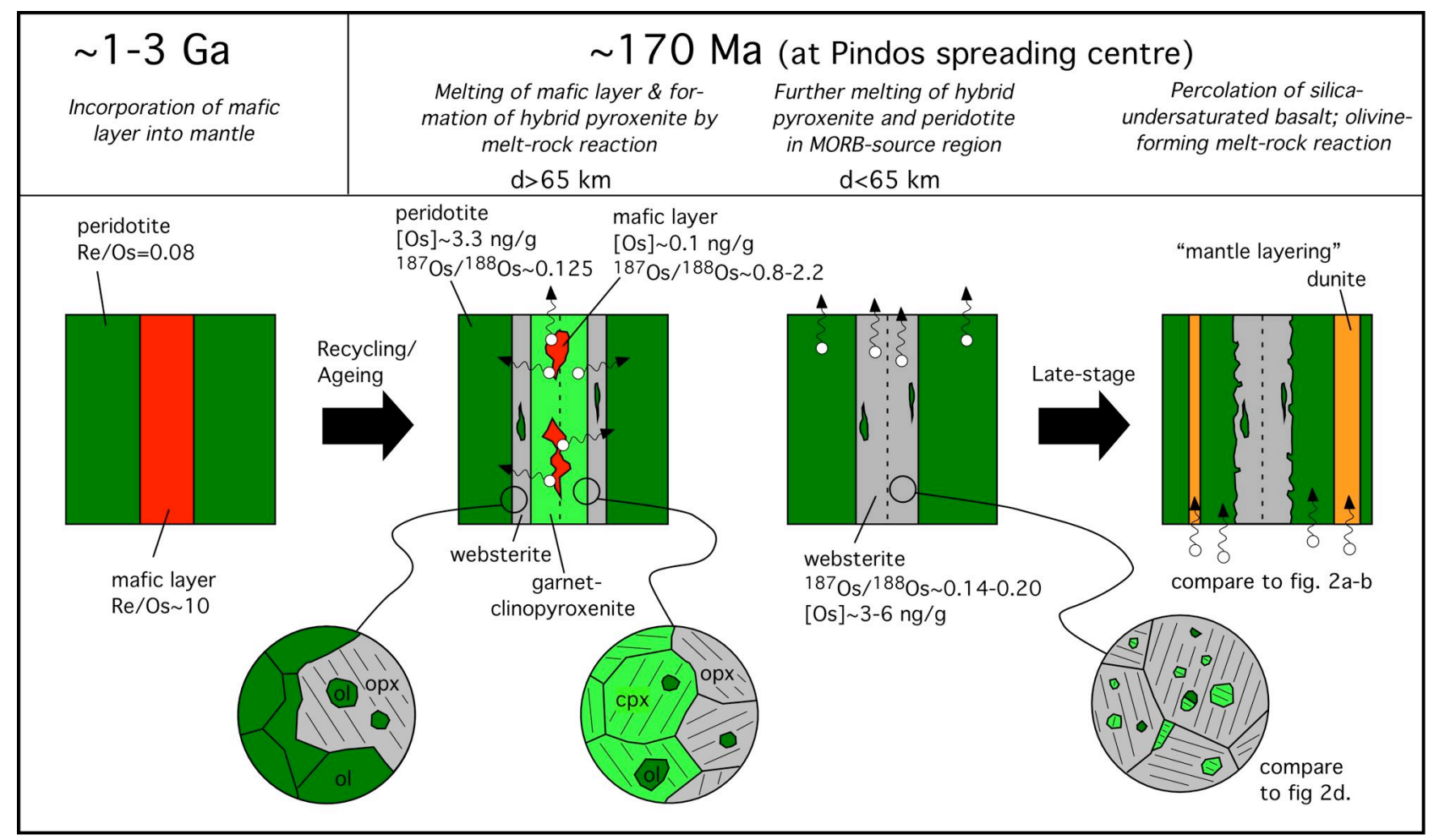

figure 6 


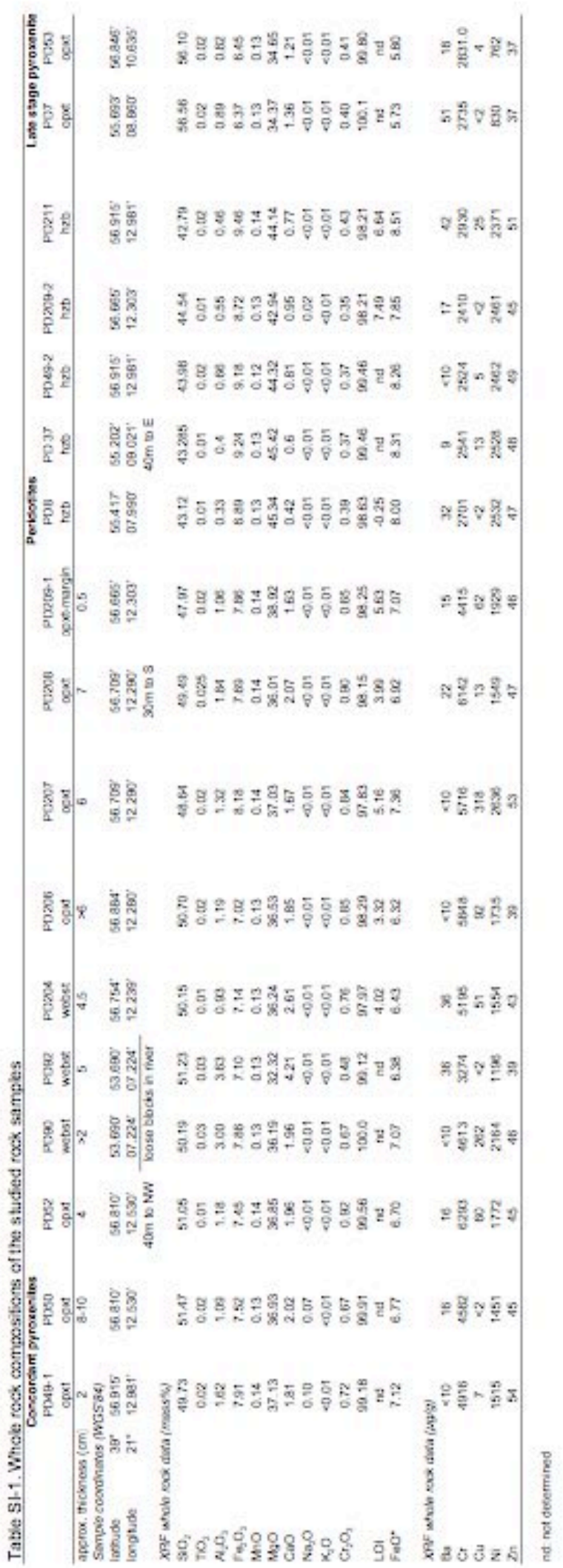




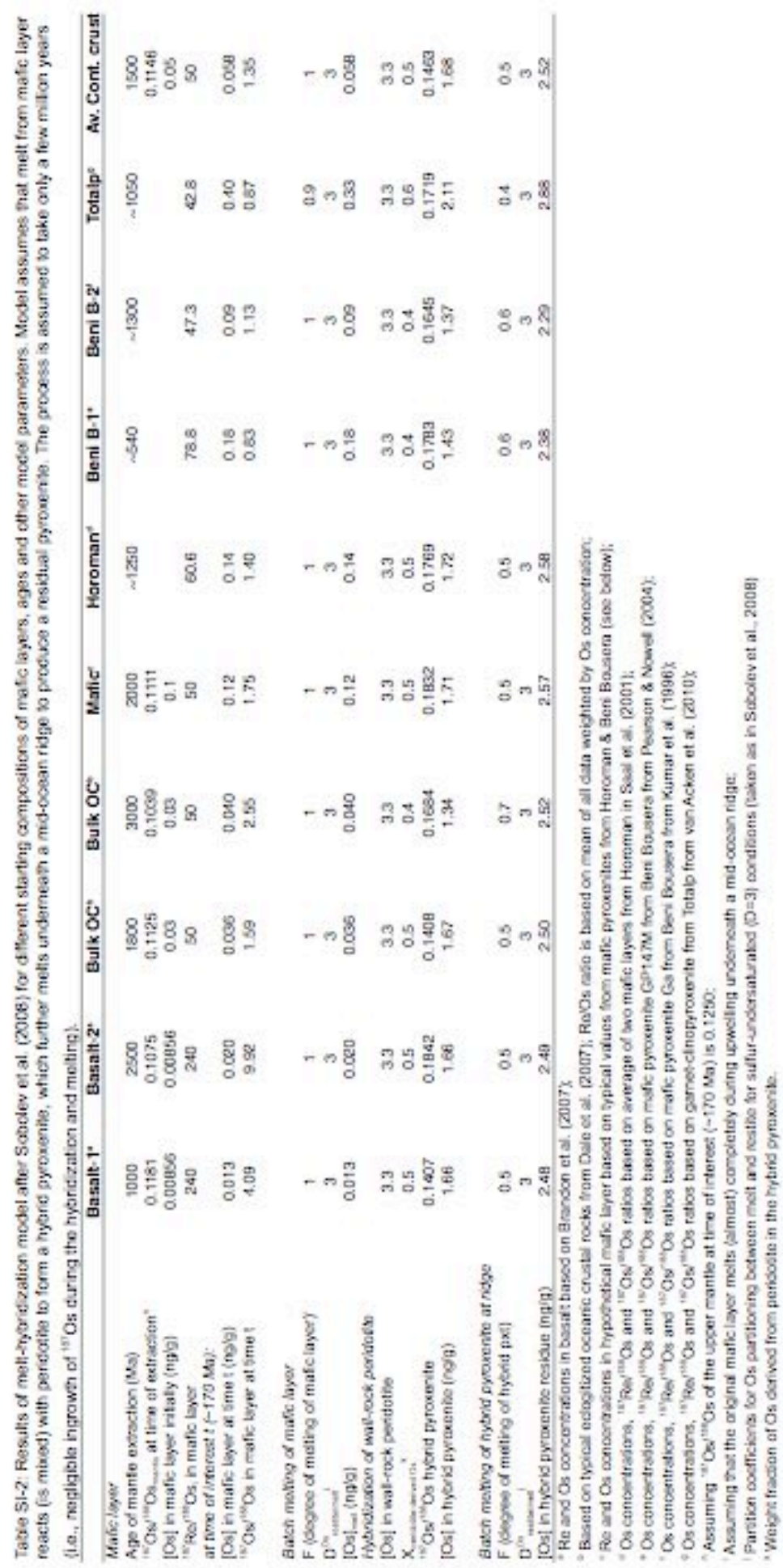




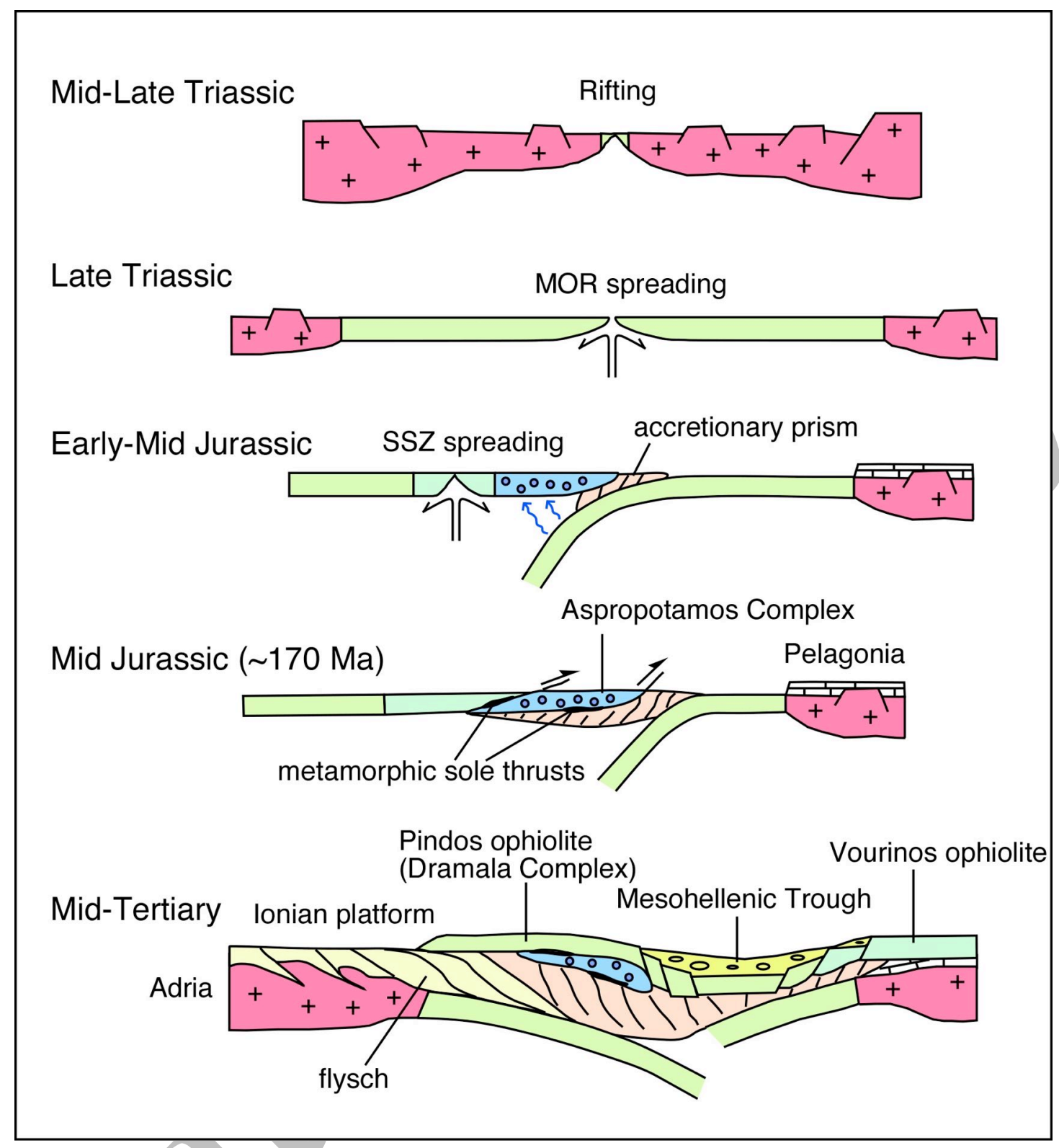

Figure SI-1. Tectonic evolution of the oceanic basin in which the Pindos Ophiolite was formed, based on reconstruction of Pe-Piper and Piper (The igneous rocks of Greece. The anatomy of an orogen. Gebrüder Borntraeger, Berlin, 2002). Note the position of the Dramala Complex (our study area) containing mostly mantle rocks associated with some lower crustal cumulates with Mid-Ocean Ridge character, and the Aspropotamos Complex, a tectonic unit comprised of volcanic and plutonic rocks with MORB, island arc tholeiite and bonninite affinities. The juxtaposition of two such different thrust sheets, with clear suprasubduction zone characteristics and with mid-ocean ridge characteristics, can be explained by the tectonicpaleogeographic reconstructions shown above: in these reconstructions, the Dramala Complex represents either Late Triassic-Early Jurassic lower oceanic crust and underlying mantle of the Neotethys, formed by mid-ocean ridge spreading before the onset of subduction in the region, or Early-Middle Jurassic oceanic crust and oceanic mantle formed in a back-arc region of the newly formed supra-subduction zone Pindos Basin, where no influence of the subduction zone is detected in the mantle. In either case, the Dramala Complex is representative for oceanic mantle from which MORB-like magmas were extracted. The Aspropotamos Complex (and the nearby Vourinos Ophiolite) represents the ocean crust that was strongly modified or newly formed by proto-arc magmatism in the fore-arc. 

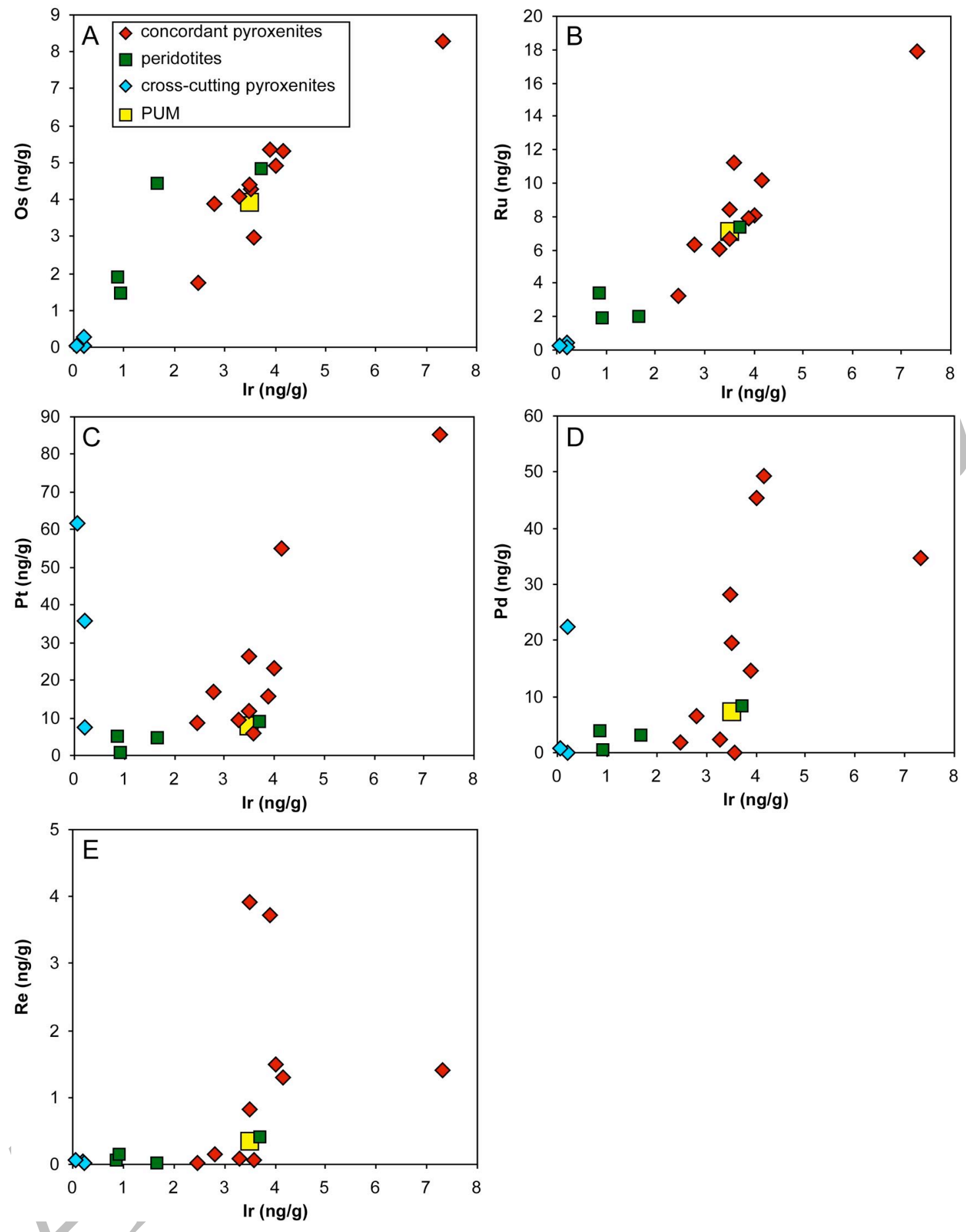

Figure SI-2 A-E. Highly siderophile element correlation diagrams for studied samples from Dramala. Yellow square represents Primitive Upper Mantle (PUM). Panels A and B show good correlations between Iridiumlike Platinum Group Elements (IPGE: Os, Ir, Ru). Panels C-E show that Pt, Pd and Re concentrations are much more variable, with values that exceed PUM, and their concentrations seem mostly decoupled from IPGE. We observed good correlations between elevated Pt, Pd and Re concentrations and the presence of grain boundary $(\mathrm{Cu}, \mathrm{Ni}, \pm \mathrm{Fe})$-sulfides in concordant pyroxenite samples. Samples enriched in $\mathrm{Pt}, \mathrm{Pd}$ and $\mathrm{Re}$ probably contain a (late-stage?) (Cu,Ni)-sulphide melt phase. In contrast, IPGE are probably hosted in $\mathrm{Fe}$ rich monosulfides and/or alloys (see Ballhaus, C., Bockrath, C., Wohlgemuth-Ueberwasser, C., Laurenz, V. \& Berndt, J., 2006. Fractionation of the noble metals by physical processes. Contrib. Mineral. Petrol. 152, 667-684). 

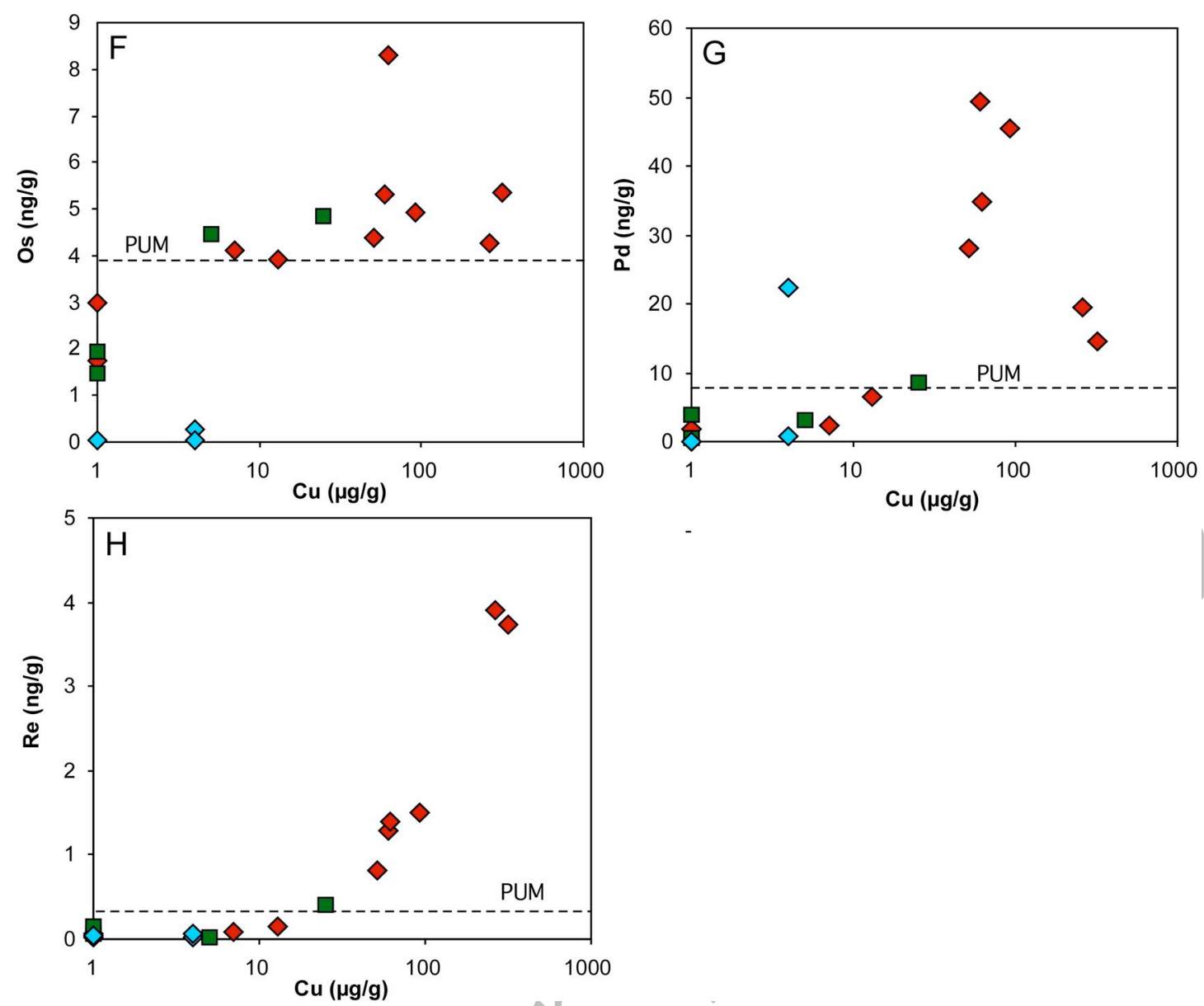

Figure SI-2 continued (panels F-H). Selected highly siderophile element concentrations vs Cu concentrations for studied samples from Dramala. Symbols as in panels A (previous page). Dashed horizontal line represents Primitive Upper Mantle (PUM) value for the HSE. Cu is used as a proxy for the presence of $(\mathrm{Cu}, \mathrm{Ni})$-sulfides, assumed to be the main host for $\mathrm{Pt}, \mathrm{Pd}$ and $\mathrm{Re}$. This is confirmed by good correlations in panels $\mathrm{G}$ and $\mathrm{H}$. In contrast, Os (and $\mathrm{Ru}$ and $\mathrm{Ir}$ ) are assumed to be hosted in Cu-poor monosulfides and/or alloys. Cu concentrations plotted at $1 \mu \mathrm{g} / \mathrm{g}$ are actually below detection limit $(2 \mu \mathrm{g} / \mathrm{g})$. 